\title{
8. CHEMICAL COMPOSITION, AGE, AND SOURCES OF VOLCANICLASTIC SEDIMENTS FROM SITES 917 AND $918^{1}$
}

\author{
Reinhard Werner, ${ }^{2}$ Paul van den Bogaard, ${ }^{2}$ Christian Lacasse, ${ }^{3}$ and Hans-Ulrich Schmincke ${ }^{2}$
}

\begin{abstract}
Volcaniclastic deposits drilled at Leg 152 Sites 917 (East Greenland Shelf) and 918 (Irminger Basin) comprise 21 Neogene ash-bearing intervals and numerous Paleogene ash layers, tuffs, lapillistones, breccias, and conglomerates. The volcanogenic components of the Neogene ash deposits consist mainly of brown to colorless glass particles with an average median grain size of $30 \mu \mathrm{m}( \pm 20 \mu \mathrm{m})$. Colorless glass particles are bubble wall shards and pumice fragments. Brown glass shards are slightly vesicular or dense blocky shards, rarely highly vesicular or pumiceous. The glass shards have subalkalic and low-K subalkalic basaltic, as well as low-K rhyolitic compositions. Rhyolitic ash layers are attributed to highly explosive plinian eruptions. Textural criteria and degree of sulfur degassing of most mafic shards suggest an origin from hydroclastic explosive fragmentation processes in a subglacial/sublacustrine eruption environment. Major element compositions indicate that most ash deposits are derived from Iceland. Only a few mafic deposits may have originated at the Reykjanes Ridge.

Abundant, highly altered Paleogene ash layers in the middle Eocene sequence of Hole 918D confirm a peak in the volcanic activity in the North Atlantic area at this period of time, as postulated in the literature. Polymict volcanic breccias and conglomerates immediately overlying flood basalts of the East Greenland Shelf are interpreted as lahars and fluvial deposits that mark the end of the intense volcanic activity in East Greenland. Altered tuffs and lapillistones within the flood basalt sequence of Site 917 are primary or reworked hydroclastic and pyroclastic deposits, reflecting rare explosive phases during the effusive eruption of the flood basalts.

Laser probe ${ }^{40} \mathrm{Ar} /{ }^{39} \mathrm{Ar}$ dating of anorthoclase and plagioclase crystals from two successions of Paleogene tuffs and lapillistones intercalated with the lavas of the Middle Series at Site 917 give mean apparent ages from $60.5 \pm 0.2$ Ma to $60.3 \pm 0.2$ Ma.
\end{abstract}

\section{INTRODUCTION}

Neogene ash-bearing sediments and Paleogene volcaniclastic layers recovered during Ocean Drilling Program (ODP) Leg 152 (East Greenland Margin) reflect the Cenozoic volcanic activity in the North Atlantic region. A total of six sites (914 through 919) were drilled along a transect at $63^{\circ} \mathrm{N}$, extending from 40 to $185 \mathrm{~km}$ east of the southeast coast of Greenland (Fig. 1). Sites 914-917 are located on the East Greenland Shelf, and Sites 918 and 919 were drilled on the continental rise of southeast Greenland within the western part of the Irminger Basin. Here, we report on volcanological and geochemical studies of volcaniclastic sediments recovered at Sites 917 and 918. Neogene tephras drilled at Site 919 are discussed by Lacasse et al. (this volume).

The aim of this study is to characterize volcanic processes in the North Atlantic area south of the Greenland-Iceland Ridge. Major element compositions indicate potential source areas of the volcaniclastic deposits. We also evaluate transport and depositional processes as well as the paleoenvironment at the time of eruption using textural criteria and volatile contents of glass particles. ${ }^{40} \mathrm{Ar} /{ }^{39} \mathrm{Ar}$ laser dating of feldspars, occurring in some Paleogene volcaniclastic deposits, provides time markers for the flood basalt sequence drilled on Site 917.

\section{Geological Setting and Statistics of Sites 917 and 918}

Site 917 represents the most inboard site in a 6-km-long profile (Sites 914-917) on the outer middle East Greenland continental

${ }^{1}$ Saunders, A.D., Larsen, H.C., and Wise, S.W., Jr. (Eds.), 1998. Proc. ODP, Sci., Results, 152: College Station, TX (Ocean Drilling Program).

${ }^{2}$ Department Volcanology and Petrology, GEOMAR, Wischhofstr. 1-3, D-24148 Kiel, Federal Republic of Germany. rwerner@geomar.de

${ }^{3}$ Graduate School of Oceanography, University of Rhode Island, Narragansett Bay Campus, Narragansett, RI 02882-1197, U.S.A. shelf. The site is located in $508 \mathrm{~m}$ of water, approximately $50 \mathrm{~km}$ from the coast of Greenland within a trough connecting deep fjords in the northwest with the continental slope and rise (Larsen, Saunders, Clift, et al., 1994). The outer shelf is characterized by the landward feather edge of the seaward-dipping reflector sequence (SDRS), a succession of baselap-free, seaward-dipping, and offlapping lava flow units. On the shelf, the SDRS is covered by up to $1.5 \mathrm{~km}$ of Paleogene and Neogene sediments. Hole 917A (Table 1) penetrated $41.9 \mathrm{~m}$ of sediments ranging in age from Quaternary to presumably latest Paleocene, a 779.2-m-thick Paleocene flood basalt sequence of the SDRS, and continued into underlying sediments. Through the deep basement penetration, the volcanic succession of Hole 917A records the development of the SDRS from the earliest volcanism to the end of the volcanic activity at this site.

Site 918 is located on the upper continental rise of the southeast Greenland margin near the center of the SDRS, approximately 130 $\mathrm{km}$ from the coast of Greenland and $750 \mathrm{~km}$ west of Iceland (Fig. 1). This site rests on oceanic crust within a broad magnetic low that is considered to be of magnetic chron C24r age (late Paleocene to early Eocene; Larsen, Saunders, Clift, et al., 1994). This volcanic basement is covered with approximately $1200 \mathrm{~m}$ of Paleogene and Neogene sediments. Four Holes (918A-D) were drilled at Site 918 in 1868$1880 \mathrm{~m}$ of water. Whereas Hole 918A penetrated a 332.7-m-thick sequence of Pliocene to Holocene sediments, only thin Quaternary sediment successions were drilled at Holes 918B and 918C. Hole 918D, however, penetrated almost $1200 \mathrm{~m}$ of sediments ranging in age from early Eocene to Holocene, reached the basaltic basement at 1189.4 meters below seafloor (mbsf) and continued $120.7 \mathrm{~m}$ into the lavas of the SDRS. The complete statistics of each hole are given in Table 1. The igneous and sedimentary sequence of Holes 918A and 918D spans a period from the Paleogene high-production volcanic phase in East Greenland to the recent volcanism in the North Atlantic region. Among others, the volcanic centers of East Greenland, the IcelandFaeroe Ridge, the Faeroe, Iceland, Jan Mayen and the Reykjanes Ridge have been active during this period (Fig. 1). 


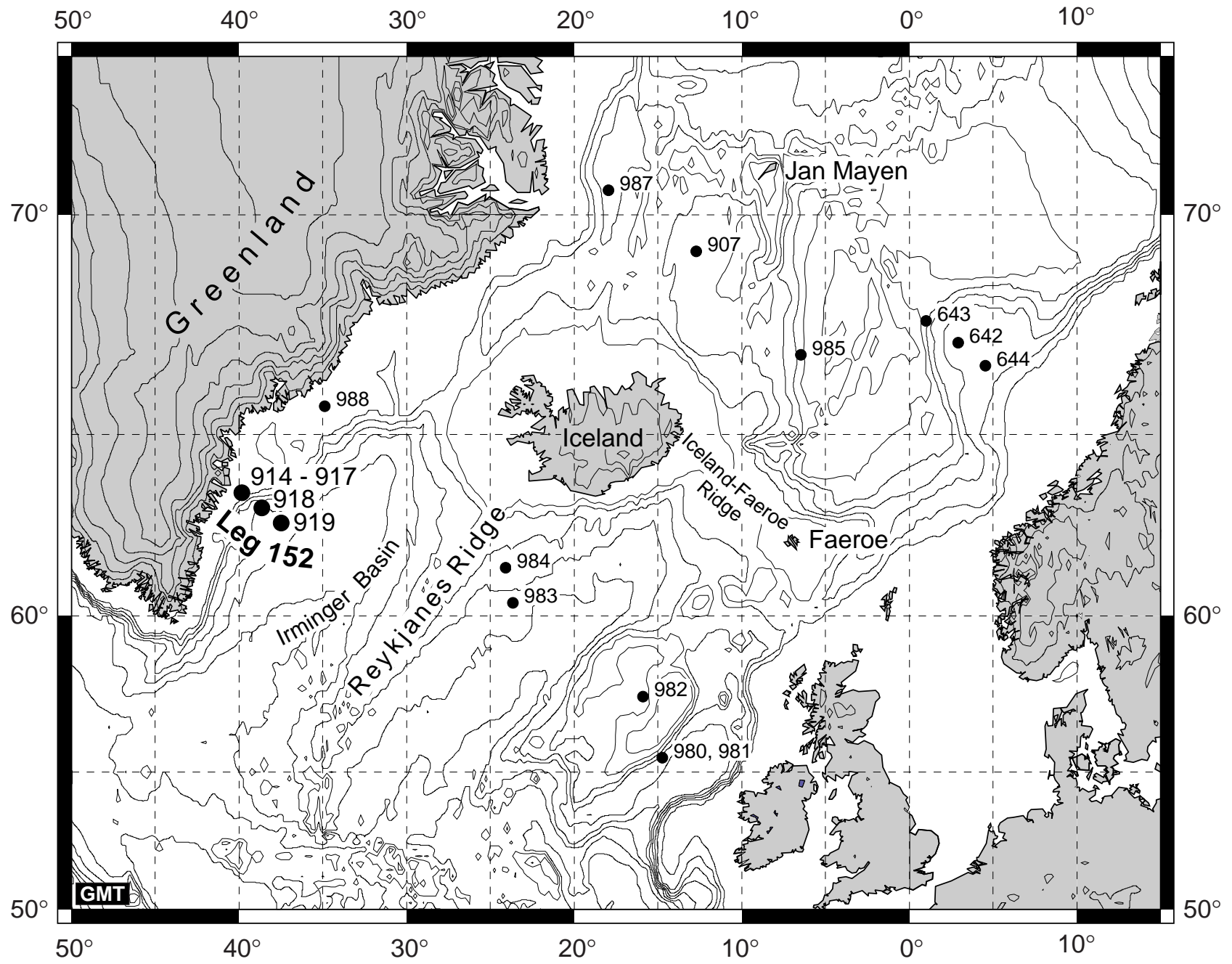

Figure 1. Map of the central North Atlantic showing locations of ODP drill sites and possible source areas for volcaniclastic sediments recovered at Sites 917 and 918.

Table 1. Statistics of the ODP Leg 152 drill sites discussed in this paper.

\begin{tabular}{|c|c|c|c|c|c|c|c|}
\hline & \multicolumn{3}{|c|}{ Outer East Greenland Shelf } & \multicolumn{4}{|c|}{ Irminger Basin } \\
\hline & $915 \mathrm{~A}$ & $916 \mathrm{~A}$ & $917 \mathrm{~A}$ & $918 \mathrm{~A}$ & $918 \mathrm{~B}$ & $918 \mathrm{C}$ & 918D \\
\hline $\begin{array}{l}\text { Latitude: } \\
\text { Longitude: }\end{array}$ & $\begin{array}{l}63^{\circ} 28.285^{\prime} \mathrm{N} \\
39^{\circ} 46.909^{\prime} \mathrm{W}\end{array}$ & $\begin{array}{l}63^{\circ} 29.137^{\prime} \mathrm{N} \\
39^{\circ} 48.400^{\prime} \mathrm{W}\end{array}$ & $\begin{array}{l}63^{\circ} 29.500^{\prime} \mathrm{N} \\
39^{\circ} 49.665^{\prime} \mathrm{W}\end{array}$ & $\begin{array}{l}63^{\circ} 5.569^{\prime} \mathrm{N} \\
38^{\circ} 38.336^{\prime} \mathrm{W}\end{array}$ & $\begin{array}{l}63^{\circ} 5.569^{\prime} \mathrm{N} \\
38^{\circ} 38.339^{\prime} \mathrm{W}\end{array}$ & $\begin{array}{l}63^{\circ} 5.575^{\prime} \mathrm{N} \\
38^{\circ} 38.328^{\prime} \mathrm{W}\end{array}$ & $\begin{array}{l}63^{\circ} 5.572^{\prime} \mathrm{N} \\
38^{\circ} 38.334^{\prime} \mathrm{W}\end{array}$ \\
\hline Water depth (m): & 533.1 & 513.7 & 508.1 & 1868.5 & 1868.2 & 1879.4 & 1879.4 \\
\hline $\begin{array}{l}\text { Total penetration }(\mathrm{m}) \text { : } \\
\text { Total length of cored section }(\mathrm{m}) \text { : } \\
\text { Drilled (mbsf): }\end{array}$ & $\begin{array}{l}209.4 \\
209.4\end{array}$ & $\begin{array}{l}101.7 \\
101.7\end{array}$ & $\begin{array}{l}874.9 \\
874.9\end{array}$ & $\begin{array}{l}332.7 \\
332.7\end{array}$ & $\begin{array}{l}25.8 \\
25.8\end{array}$ & $\begin{array}{r}35.4 \\
9.6 \\
0-25.8\end{array}$ & $\begin{array}{l}1310.1 \\
1012.8 \\
0-253.2\end{array}$ \\
\hline Core recovery $(\%)$ : & 15.7 & 16.9 & 52.0 & 78.2 & 98.8 & 100.4 & $\begin{array}{c}279.9-324.0 \\
25.1\end{array}$ \\
\hline $\begin{array}{l}\text { Oldest sediment cored: } \\
\text { Depth (mbsf) } \\
\text { Earliest age }\end{array}$ & $\begin{array}{c}196.8 \\
\text { Eocene (?) }\end{array}$ & $\begin{array}{c}101.7 \\
\text { Eocene (?) }\end{array}$ & $\begin{array}{c}874.9 \\
\text { Paleocene (?) }\end{array}$ & $\begin{array}{c}332.7 \\
\text { Pliocene }\end{array}$ & $\begin{array}{c}25.8 \\
\text { Quaternary }\end{array}$ & $\begin{array}{c}35.4 \\
\text { Quaternary }\end{array}$ & $\begin{array}{c}1189.4 \\
\text { early Eocene }\end{array}$ \\
\hline Igneous rocks cored (mbsf): & $189.3-209.4$ & & $41.9-820.7$ & & & & $\begin{array}{l}1168.2-1180.4 \\
1189.4-1310.1\end{array}$ \\
\hline Lithostratigraphic summary: & Fig. 8 & Fig. 8 & Fig. 8 & Fig. 2 & & & Figs. 2,8 \\
\hline
\end{tabular}

Note: Data taken from Larsen, Saunders, Clift, et al. (1994). 


\section{METHODS}

All ash-bearing sediments and other volcaniclastic deposits that have been identified by the Shipboard Scientific Party (Larsen, Saunders, Clift, et al., 1994) were sampled on the JOIDES Resolution. Thin sections were made from all samples possibly containing fresh glass particles as well as from 41 other volcaniclastic deposits. Twenty-one Neogene ash deposits and four Paleogene volcaniclastic deposits were selected for detailed studies.

Texture, mineralogical and lithological composition, and alteration were studied in thin sections. For samples containing fresh glass particles, maximum diameter of a particle and the smallest distance between two points through which the particle still fits were measured using calibrated ocular scales. Fifty to 80 individual glass particles and additionally the five largest shards were measured in each thin section. The grain-size data presented in this paper are the arithmetic means of these measurements ("medium diameter"). Relative abundance of different clast types was determined by counting about 300 grains per thin section (Table 2).

Major element compositions and volatile contents $(\mathrm{S}, \mathrm{Cl}$, and $\mathrm{F}$ ) of fresh glass particles and major element compositions of feldspars were determined using a CAMECA SX50 electron microprobe (EMP). The EMP was operated at an accelerating voltage of $15 \mathrm{kV}$ and a beam current of $10 \mathrm{nA}$. To minimize sodium loss, felsic glasses were analyzed with the beam rastered (TV mode) scanning an area of $9.5 \times 13 \mu \mathrm{m}$ (magnification 10,000). Natural glass standards JDF-D2 (mid-ocean-ridge basalt [MORB]-glass) and LIPARI (obsidian, Lipari, Cannetto Lami lava), and mineral standards PLAG and ALBIT were used for calibration. Additional basaltic and rhyolitic glass standards (e.g., KN 18, VG-2) and interlaboratory monitors were analyzed periodically to monitor the accuracy of the microprobe. To smooth out compositional heterogeneities, up to 8 points were analyzed on each glass particle. The data presented here are averages of these analyses. Up to 30 individual glass particles were analyzed for each ash deposit (Tables 3,4). The standard CHALCOPYRIT was used to calibrate the EMP sulfur analyses. The accuracy of the sulfur analyses is estimated to be \pm 20 parts per million (ppm).

Bulk rock analyses of volcaniclastic deposits were performed using a Philips X unique X-ray fluorescence (XRF) spectrometer (stan- dards: BHVO-1 Hawaiian basalt, AGV-1 andesite, and RGM-1 rhyolite).

Age determinations were carried out by ${ }^{40} \mathrm{Ar} /{ }^{39} \mathrm{Ar}$ laser dating on 70 single feldspar crystals from Site 917, applying a 25 W Spectraphysics Argon Ion laser and a MAP 216 series noble gas mass spectrometer. Three sets of irradiations were carried out in the $5 \mathrm{MW}$ reactor at the GKSS Research Center (Geesthacht, Federal Republic of Germany): Vial "CAN10" was irradiated for $3 \mathrm{hr}$ without Cd liner in the reactor core, received an average neutron flux of $8.7 \times 10^{12} \mathrm{~N} /$ $\left(\mathrm{cm}^{2} \times \mathrm{s}\right)$, and contained nine feldspar crystals from Sample 152917A-24R-1, 6-8 cm. Vials "CAN8" and "CAN13" were irradiated for $72 \mathrm{hr}$ with a $0.5-\mathrm{mm} \mathrm{Cd}$ liner, received an average fast neutron flux of $2.1 \times 10^{12} \mathrm{~N} / \mathrm{cm}^{2} \times \mathrm{s}$, and contained 20 feldspar crystals from Samples 152-917A-23R-2, 127-131 cm; 23R-3, 14-17 cm; and 24R1, 1-3 cm (CAN8), and 41 feldspar crystals from Samples 152-917A24R-1, 6-8 cm; 23R-2, 127-131 cm; 23R-3, 14-17 cm; 24R-1, 1-3 $\mathrm{cm}$; and 53R-1, 80-83 cm (CAN13). In CAN10, MMhb-1 hornblende crystals (520.4 $\pm 1.7 \mathrm{Ma}$, Samson and Alexander, 1987) were applied as irradiation monitors. In CAN8 and CAN13 the neutron flux was monitored using TCR sanidine (27.92 Ma; Dalrymple and Duffield, 1988). Monitor minerals and samples were irradiated in aluminum sample holders, spatially defined sample positions providing control on both vertical and lateral neutron flux gradients. Vertical variations in J-value were corrected by fitting a cosine function curve to the data.

Typical system blanks are $4 \times 10^{-14} \mathrm{~cm}^{3}$ standard temperature and pressure (STP), $1 \times 10^{-13} \mathrm{~cm}^{3} \mathrm{STP}$, and $2 \times 10^{-13} \mathrm{~cm}^{3} \mathrm{STP}$ at masses 36,39 , and 40 , the total volume of mass spectrometer plus inlet system approximating $1800 \mathrm{~cm}^{3}$. Raw mass spectrometer peaks were corrected for mass discrimination and interfering neutron reactions (Bogaard, 1995; Bogaard and Schirnick, 1995). All analyses were conducted at the GEOMAR Tephrochronology Laboratory.

\section{NEOGENE ASH-BEARING SEDIMENTS}

Site 919 and the Pliocene and Pleistocene sedimentary sequence of Hole 918A contain the majority of Neogene ash-bearing sediments drilled during Leg 152 (Fig. 2). Fifteen layers with significant

Table 2. Type, stratigraphic setting, textural characteristics, and composition of ash layers and ash-bearing sediments recovered at Site 918.

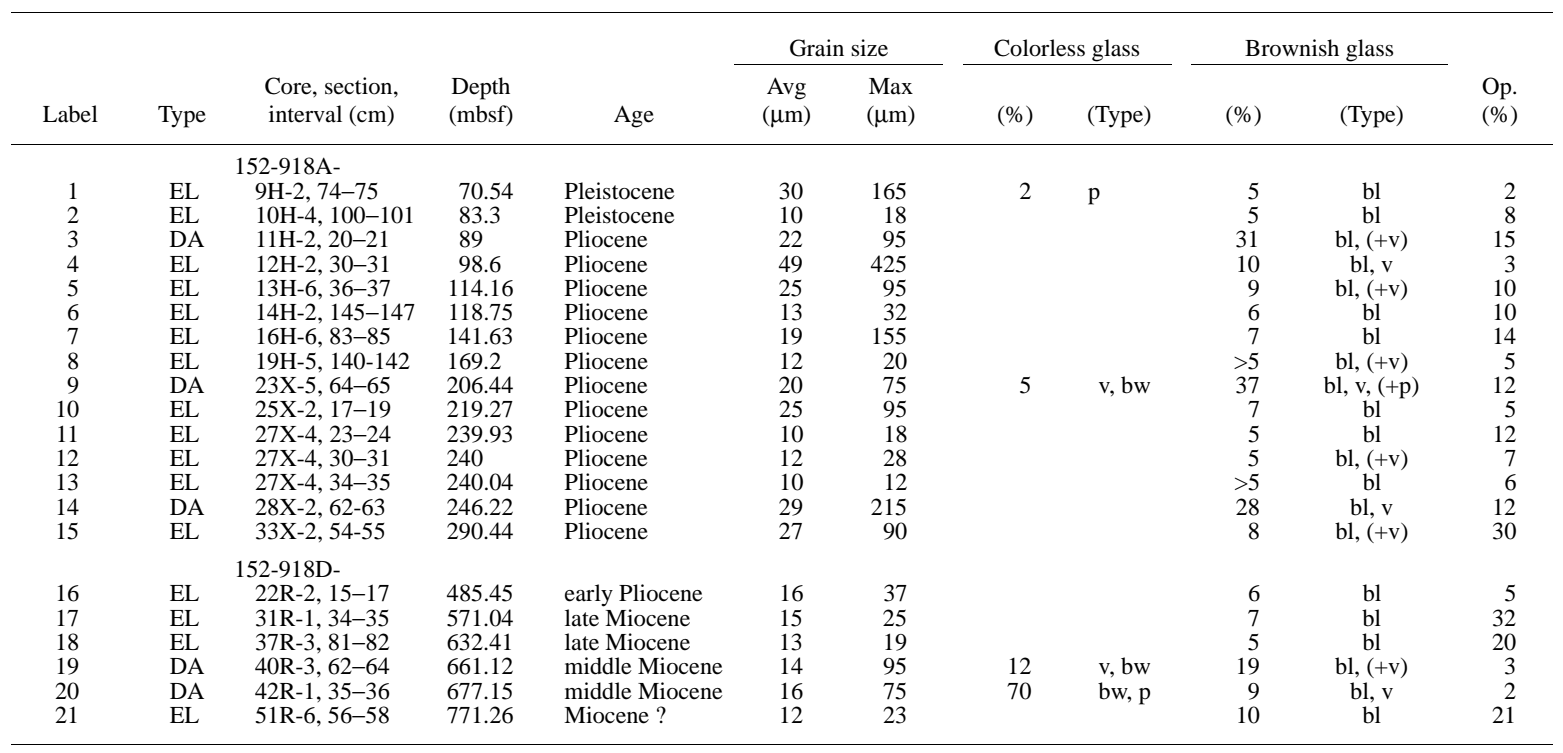

Notes: With a few exceptions, depth, thickness and ages taken from Larsen, Saunders, Clift, et al. (1994). DA = disseminated ash layer, EL = ash-enriched ash layer. Avg = average grain size, Max = maximum grain size (for explanation see "Methods" section of this study). \% = volume percentage (for explanation see "Methods" section). $\mathrm{v}=$ vesicular shards, bw $=$ bubble wall shards, $\mathrm{p}=$ pumice fragments. $\mathrm{bl}=$ blocky shards, $(+\mathrm{p})=$ sample contains subordinate pumice fragments. Op. $=$ tachylite and opaque clasts. 
Table 3. Electron microprobe analyses of mafic glassy tephra recovered at Site 918.

\begin{tabular}{|c|c|c|c|c|c|c|c|c|c|c|}
\hline $\begin{array}{l}\text { Core, section: } \\
\text { Interval }(\mathrm{cm}) \text { : } \\
\text { Label: } \\
\text { Type: } \\
\text { Part./points: } \\
\text { Share: }\end{array}$ & $\begin{array}{r}152-918 \\
74- \\
\mathrm{E} \\
6 \mathrm{f} / \\
10 \\
\end{array}$ & & $\begin{array}{r}152-918 \\
20- \\
3(\mathrm{pc} \\
\mathrm{D} \\
18 \mathrm{f} / \\
90\end{array}$ & $\mathrm{H}-2$ & $\begin{array}{r}152-918 \mathrm{~A}-1 \\
20-21 \\
3 \text { (pop. } \\
\text { DA } \\
2 \mathrm{f} / 8 \mathrm{p} \\
10 \% \\
\end{array}$ & & $\begin{array}{r}152-918 \mathrm{~A}- \\
30-31 \\
4 \\
\mathrm{EL} \\
6 \mathrm{f} / 17_{1} \\
100 \%\end{array}$ & & $\begin{array}{r}\text { 152-918A- } \\
36-37 \\
5 \text { (pop. } \\
\text { EL } \\
16 \mathrm{f} / 60 \\
84 \%\end{array}$ & \\
\hline Share: & Average & $\mathrm{SD}$ & Average tre & SD & Average hetero & SD & Average hetero & SD & Average & $\mathrm{SD}$ \\
\hline $\begin{array}{l}\mathrm{SiO}_{2} \\
\mathrm{TiO}_{2} \\
\mathrm{Al}_{2} \mathrm{O}_{3} \\
\mathrm{FeO} \\
\mathrm{MnO} \\
\mathrm{MgO} \\
\mathrm{CaO} \\
\mathrm{Na}_{2} \mathrm{O} \\
\mathrm{K}_{2} \mathrm{O} \\
\mathrm{P}_{2} \mathrm{O}_{5}\end{array}$ & $\begin{array}{r}50.06 \\
2.03 \\
14.25 \\
12.54 \\
0.21 \\
7.10 \\
11.70 \\
2.42 \\
0.23 \\
0.22\end{array}$ & $\begin{array}{l}0.46 \\
0.25 \\
0.15 \\
0.38 \\
0.04 \\
0.40 \\
0.49 \\
0.12 \\
0.07 \\
0.03\end{array}$ & $\begin{array}{r}49.37 \\
3.03 \\
13.36 \\
14.19 \\
0.24 \\
5.75 \\
10.24 \\
2.82 \\
0.45 \\
0.35\end{array}$ & $\begin{array}{l}0.99 \\
0.73 \\
0.57 \\
1.27 \\
0.03 \\
0.78 \\
0.98 \\
0.23 \\
0.21 \\
0.14\end{array}$ & $\begin{array}{r}51.89 \\
3.10 \\
13.46 \\
13.97 \\
0.29 \\
3.86 \\
7.99 \\
3.51 \\
0.87 \\
0.64\end{array}$ & $\begin{array}{l}1.73 \\
0.47 \\
0.19 \\
0.44 \\
0.04 \\
0.01 \\
0.02 \\
0.29 \\
0.21 \\
0.27\end{array}$ & $\begin{array}{r}50.46 \\
3.28 \\
13.20 \\
14.82 \\
0.26 \\
4.80 \\
9.13 \\
2.99 \\
0.61 \\
0.35\end{array}$ & $\begin{array}{l}0.52 \\
0.53 \\
0.45 \\
0.98 \\
0.03 \\
0.91 \\
1.31 \\
0.17 \\
0.20 \\
0.12\end{array}$ & $\begin{array}{r}49.09 \\
2.27 \\
13.71 \\
13.03 \\
0.22 \\
6.75 \\
11.29 \\
2.57 \\
0.23 \\
0.22\end{array}$ & $\begin{array}{l}0.26 \\
0.11 \\
0.12 \\
0.25 \\
0.03 \\
0.10 \\
0.23 \\
0.05 \\
0.03 \\
0.03\end{array}$ \\
\hline$\sum$ (vol.-free) & 100.75 & & 99.80 & & 99.58 & & 99.89 & 0.35 & 99.38 & \\
\hline $\begin{array}{l}\mathrm{SO}_{2} \\
\mathrm{~F} \\
\mathrm{Cl}\end{array}$ & $\begin{array}{l}0.13 \\
0.09 \\
0.03\end{array}$ & $\begin{array}{l}0.05 \\
0.04 \\
0.01\end{array}$ & $\begin{array}{l}0.15 \\
0.13 \\
0.02\end{array}$ & $\begin{array}{l}0.06 \\
0.03 \\
0.02\end{array}$ & $\begin{array}{l}0.17 \\
0.16 \\
0.04\end{array}$ & $\begin{array}{l}0.07 \\
0.05 \\
0.02\end{array}$ & $\begin{array}{l}0.12 \\
0.16 \\
0.03\end{array}$ & $\begin{array}{l}0.04 \\
0.04 \\
0.01\end{array}$ & $\begin{array}{l}0.18 \\
0.11 \\
0.02\end{array}$ & $\begin{array}{l}0.02 \\
0.02 \\
0.01\end{array}$ \\
\hline Total & \multicolumn{2}{|l|}{101.01} & \multicolumn{2}{|l|}{100.11} & \multicolumn{2}{|l|}{99.95} & \multicolumn{2}{|l|}{100.20} & \multicolumn{2}{|l|}{99.68} \\
\hline $\begin{array}{l}\text { Core, section: } \\
\text { Interval }(\mathrm{cm}) \text { : } \\
\text { Label: } \\
\text { Type: } \\
\text { Part./points: } \\
\text { Share: }\end{array}$ & $\begin{array}{r}152-918 \\
36 \\
5(\mathrm{po} \\
\mathrm{E} \\
3 \mathrm{f} \\
16\end{array}$ & & $\begin{array}{r}152-918 \\
83- \\
7(\mathrm{pc} \\
\mathrm{E} \\
3 \mathrm{f} / \\
30\end{array}$ & & $\begin{array}{r}\text { 152-918A-1 } \\
83-85 \\
7 \text { (pop. } \\
\text { EL } \\
7 \mathrm{f} / 21 \mathrm{p} \\
70 \% \\
\end{array}$ & & $\begin{array}{r}152-918 \mathrm{~A}- \\
64-65 \\
9 \\
\mathrm{DA} \\
6 \mathrm{f} / 15 \\
100 \% \\
\end{array}$ & & $\begin{array}{r}152-918 \mathrm{~A}- \\
17-1 \mathrm{C} \\
10 \\
\mathrm{EL} \\
6 \mathrm{f} / 14 \\
100 \% \\
\end{array}$ & \\
\hline & Average & SD & Average & $\mathrm{SD}$ & Average hetero & SD & Average & SD & Average trend & $\mathrm{SD}$ \\
\hline $\begin{array}{l}\mathrm{SiO}_{2} \\
\mathrm{TiO}_{2} \\
\mathrm{Al}_{2} \mathrm{O}_{3} \\
\mathrm{FeO} \\
\mathrm{MnO} \\
\mathrm{MgO} \\
\mathrm{CaO} \\
\mathrm{Na}_{2} \mathrm{O} \\
\mathrm{K}_{2} \mathrm{O} \\
\mathrm{P}_{2} \mathrm{O}_{5}\end{array}$ & $\begin{array}{r}48.12 \\
3.43 \\
13.08 \\
15.55 \\
0.25 \\
5.62 \\
9.66 \\
2.73 \\
0.44 \\
0.42\end{array}$ & $\begin{array}{l}0.96 \\
0.45 \\
0.11 \\
0.99 \\
0.02 \\
0.10 \\
0.16 \\
0.02 \\
0.03 \\
0.08\end{array}$ & $\begin{array}{r}48.34 \\
2.50 \\
13.65 \\
13.45 \\
0.19 \\
6.73 \\
11.18 \\
2.58 \\
0.26 \\
0.27\end{array}$ & $\begin{array}{l}0.69 \\
0.13 \\
0.26 \\
0.03 \\
0.03 \\
0.07 \\
0.22 \\
0.04 \\
0.01 \\
0.10\end{array}$ & $\begin{array}{r}49.01 \\
3.05 \\
13.14 \\
14.58 \\
0.26 \\
5.43 \\
9.70 \\
2.84 \\
0.54 \\
0.48\end{array}$ & $\begin{array}{l}1.31 \\
0.69 \\
0.60 \\
1.38 \\
0.03 \\
0.81 \\
0.83 \\
0.30 \\
0.42 \\
0.45\end{array}$ & $\begin{array}{r}50.14 \\
3.27 \\
13.36 \\
14.36 \\
0.24 \\
5.28 \\
9.29 \\
2.83 \\
0.49 \\
0.41\end{array}$ & $\begin{array}{l}0.29 \\
0.24 \\
0.30 \\
0.57 \\
0.04 \\
0.33 \\
0.53 \\
0.04 \\
0.09 \\
0.06\end{array}$ & $\begin{array}{r}50.13 \\
3.05 \\
13.72 \\
13.73 \\
0.22 \\
5.59 \\
9.72 \\
2.90 \\
0.51 \\
0.36\end{array}$ & $\begin{array}{l}0.57 \\
0.40 \\
0.58 \\
1.08 \\
0.02 \\
0.87 \\
0.75 \\
0.24 \\
0.30 \\
0.08\end{array}$ \\
\hline$\sum$ (vol.-free) & 99.30 & & 99.15 & & 99.05 & & 99.66 & & 99.93 & \\
\hline $\begin{array}{l}\mathrm{SO}_{2} \\
\mathrm{~F} \\
\mathrm{Cl}\end{array}$ & $\begin{array}{l}0.21 \\
0.15 \\
0.03\end{array}$ & $\begin{array}{l}0.08 \\
0.02 \\
0.01\end{array}$ & $\begin{array}{l}0.17 \\
0.14 \\
0.03\end{array}$ & $\begin{array}{l}0.02 \\
0.01 \\
0.01\end{array}$ & $\begin{array}{l}0.18 \\
0.15 \\
0.04\end{array}$ & $\begin{array}{l}0.04 \\
0.05 \\
0.03\end{array}$ & $\begin{array}{l}0.18 \\
0.15 \\
0.02\end{array}$ & $\begin{array}{l}0.05 \\
0.02 \\
0.00\end{array}$ & $\begin{array}{l}0.16 \\
0.15 \\
0.02\end{array}$ & $\begin{array}{l}0.09 \\
0.05 \\
0.02\end{array}$ \\
\hline Total & 99.68 & & 99.49 & & 99.41 & & 100.02 & & 100.26 & \\
\hline $\begin{array}{l}\text { Core, section: } \\
\text { Interval }(\mathrm{cm}) \text { : } \\
\text { Label: } \\
\text { Type: } \\
\text { Part./points: } \\
\text { Share: }\end{array}$ & $\begin{array}{r}152-918 \\
62- \\
14(\mathrm{p} \\
\mathrm{D} \\
12 \mathrm{f} \\
60\end{array}$ & & $\begin{array}{r}152-918 \\
62- \\
14(\mathrm{p} \\
\mathrm{D} \\
8 \mathrm{f} / \\
40\end{array}$ & & $\begin{array}{r}152-918 \mathrm{~A}-3 \\
54-55 \\
15 \\
\mathrm{EL} \\
20 \mathrm{f} / 59_{1} \\
100 \% \\
\end{array}$ & & $\begin{array}{r}152-918 \mathrm{D}- \\
62-64 \\
19 \\
(\mathrm{DA}) \\
6 \mathrm{f} / 13 \mathrm{H} \\
100 \% \\
\end{array}$ & & $\begin{array}{r}152-918 \mathrm{D}- \\
35-36 \\
20 \\
(\mathrm{DA}) \\
2 \mathrm{f} / 8 \mathrm{p} \\
100 \% \\
\end{array}$ & \\
\hline & Average & SD & Average & SD & Average trend & SD & Average trend & SD & Average hetero & $\mathrm{SD}$ \\
\hline $\begin{array}{l}\mathrm{SiO}_{2} \\
\mathrm{TiO}_{2} \\
\mathrm{Al}_{2} \mathrm{O}_{3} \\
\mathrm{FeO} \\
\mathrm{MnO} \\
\mathrm{MgO} \\
\mathrm{CaO} \\
\mathrm{Na}_{2} \mathrm{O} \\
\mathrm{K}_{2} \mathrm{O} \\
\mathrm{P}_{2} \mathrm{O}_{5}\end{array}$ & $\begin{array}{r}49.68 \\
3.35 \\
12.95 \\
15.30 \\
0.24 \\
5.30 \\
9.66 \\
2.77 \\
0.45 \\
0.35\end{array}$ & $\begin{array}{l}0.20 \\
0.08 \\
0.07 \\
0.11 \\
0.02 \\
0.05 \\
0.19 \\
0.03 \\
0.01 \\
0.01\end{array}$ & $\begin{array}{r}49.77 \\
3.76 \\
12.32 \\
16.43 \\
0.26 \\
4.54 \\
8.91 \\
2.89 \\
0.52 \\
0.39\end{array}$ & $\begin{array}{l}0.23 \\
0.10 \\
0.10 \\
0.22 \\
0.03 \\
0.12 \\
0.19 \\
0.05 \\
0.02 \\
0.01\end{array}$ & $\begin{array}{r}49.33 \\
3.19 \\
13.08 \\
14.68 \\
0.23 \\
5.39 \\
9.72 \\
2.89 \\
0.49 \\
0.36\end{array}$ & $\begin{array}{l}0.83 \\
0.66 \\
0.36 \\
0.90 \\
0.03 \\
0.69 \\
0.88 \\
0.18 \\
0.15 \\
0.08\end{array}$ & $\begin{array}{r}49.57 \\
3.16 \\
13.31 \\
13.48 \\
0.24 \\
5.53 \\
10.17 \\
2.83 \\
0.51 \\
0.36\end{array}$ & $\begin{array}{l}0.62 \\
0.78 \\
0.66 \\
1.30 \\
0.05 \\
1.00 \\
1.25 \\
0.26 \\
0.19 \\
0.10\end{array}$ & $\begin{array}{r}47.24 \\
2.03 \\
11.70 \\
16.87 \\
0.34 \\
7.17 \\
10.79 \\
2.07 \\
0.83 \\
0.21\end{array}$ & $\begin{array}{l}4.07 \\
1.77 \\
1.81 \\
4.42 \\
0.15 \\
2.15 \\
1.18 \\
1.05 \\
0.54 \\
0.21\end{array}$ \\
\hline$\sum$ (vol.-free) & 100.06 & & 99.78 & & 99.36 & & 99.15 & & 99.24 & \\
\hline $\begin{array}{l}\mathrm{SO}_{2} \\
\mathrm{~F} \\
\mathrm{Cl}\end{array}$ & $\begin{array}{l}0.19 \\
0.13 \\
0.02\end{array}$ & $\begin{array}{l}0.05 \\
0.02 \\
0.01\end{array}$ & $\begin{array}{l}0.22 \\
0.14 \\
0.03\end{array}$ & $\begin{array}{l}0.03 \\
0.02 \\
0.01\end{array}$ & $\begin{array}{l}0.16 \\
0.13 \\
0.03\end{array}$ & $\begin{array}{l}0.06 \\
0.03 \\
0.02\end{array}$ & $\begin{array}{l}0.12 \\
0.12 \\
0.03\end{array}$ & $\begin{array}{l}0.04 \\
0.02 \\
0.02\end{array}$ & $\begin{array}{l}0.06 \\
0.24 \\
0.08\end{array}$ & $\begin{array}{l}0.05 \\
0.16 \\
0.06\end{array}$ \\
\hline Total & 100.40 & & 100.17 & & 99.68 & & 99.42 & & 99.62 & \\
\hline
\end{tabular}

Notes: $($ pop. $)=$ chemically different population of glass particles within an individual deposit. DA $=$ disseminated ash layer, EL $=$ ash-enriched layer, and type in parentheses $(\mathrm{DA})=$ subordinate mafic component in a silicic deposit. Part./points = number of analyzed particles (f) and total number of analyses (p). Share $=$ share of the total number of analyzed mafic glass particles within an individual deposit (amounts to $100 \%$ unless the deposit consists of several chemically different populations); Average trend $=$ average of a group of analyses showing a clear trend; Average hetero = average of a group of chemically heterogeneous particles within an individual deposit; and SD = standard deviation . 
Table 4. Electron microprobe analyses of silicic glassy tephra recovered at Hole 918D.

\begin{tabular}{|c|c|c|c|c|c|c|}
\hline $\begin{array}{l}\text { Core, section: } \\
\text { Interval }(\mathrm{cm}) \text { : } \\
\text { Label: } \\
\text { Type: } \\
\text { Part./points: } \\
\text { Share: }\end{array}$ & $\begin{array}{r}152-918 \mathrm{D}-4 \\
60-64 \\
19 \\
\text { DA } \\
3 \mathrm{f} / 6 \mathrm{p} \\
100 \%\end{array}$ & & $\begin{array}{r}152-9181 \\
35- \\
20(\mathrm{p} \\
\mathrm{D} \\
17 \mathrm{f} / \\
8\end{array}$ & & $\begin{array}{r}152-918 \\
35- \\
20(\mathrm{p} \\
\mathrm{D} \\
4 \mathrm{f} / \\
19\end{array}$ & \\
\hline & Average hetero & SD & Average & $\mathrm{SD}$ & Average & SD \\
\hline $\begin{array}{l}\mathrm{SiO}_{2} \\
\mathrm{TiO}_{2} \\
\mathrm{Al}_{2} \mathrm{O}_{3} \\
\mathrm{FeO} \\
\mathrm{MnO} \\
\mathrm{CaO} \\
\mathrm{Na}_{2} \mathrm{O} \\
\mathrm{K}_{2} \mathrm{O} \\
\mathrm{P}_{2} \mathrm{O}_{5}\end{array}$ & $\begin{array}{r}72.42 \\
0.31 \\
11.45 \\
2.94 \\
0.10 \\
1.68 \\
2.90 \\
1.98 \\
0.06\end{array}$ & $\begin{array}{l}1.71 \\
0.12 \\
0.43 \\
0.62 \\
0.05 \\
0.40 \\
0.18 \\
0.48 \\
0.02\end{array}$ & $\begin{array}{r}73.88 \\
0.10 \\
12.18 \\
1.22 \\
0.04 \\
1.21 \\
2.99 \\
2.94 \\
0.05\end{array}$ & $\begin{array}{l}0.20 \\
0.04 \\
0.04 \\
0.05 \\
0.01 \\
0.03 \\
0.07 \\
0.10 \\
0.01\end{array}$ & $\begin{array}{r}72.04 \\
11.79 \\
11.79 \\
2.81 \\
0.01 \\
0.97 \\
3.41 \\
2.95 \\
0.04\end{array}$ & $\begin{array}{l}0.36 \\
0.04 \\
0.04 \\
0.02 \\
0.00 \\
0.03 \\
0.10 \\
0.12 \\
0.01\end{array}$ \\
\hline $\begin{array}{l}\sum(\text { vol.-free }) \\
\mathrm{SO}_{2} \\
\mathrm{~F} \\
\mathrm{Cl}\end{array}$ & $\begin{array}{r}93.97 \\
0.02 \\
0.09 \\
0.03\end{array}$ & $\begin{array}{l}0.02 \\
0.02 \\
0.02\end{array}$ & $\begin{array}{r}94.77 \\
0.01 \\
0.07 \\
0.02\end{array}$ & $\begin{array}{l}0.01 \\
0.02 \\
0.01\end{array}$ & $\begin{array}{r}94.37 \\
0.03 \\
0.16 \\
0.12\end{array}$ & $\begin{array}{l}0.01 \\
0.02 \\
0.01\end{array}$ \\
\hline Total & 94.11 & & 94.88 & & 94.68 & \\
\hline
\end{tabular}

Abbreviations: $($ pop) $=$ chemically homogeneous population of glass particles in an individual deposit. DA $=$ disseminated ash layer. Part./points $=$ number of analyzed particles (f) and total number of analyses (p). Share $=$ percentage of all analyzed silicic glass particles in the individual deposit. Average hetero $=$ average of a group of chemical heterogeneous particles in an individual deposit, and $\mathrm{SD}=$ standard deviation.

amounts of fresh glass particles were identified in Hole 918A. In addition, one lower Pliocene and five Miocene ash deposits were found in lithologic Units I and II of Hole 918D between 485.5 and 771.3 mbsf.

\section{Structure and Stratigraphic Distribution}

In the sedimentary sequence of Holes 918A and 918D, volcanic glass occurs as light to dark brown sideromelane, tachylitic, and colorless silicic fragments in horizons with glass particle contents varying from less than $5 \%$ to more than $80 \%$. Because of the lack of distinct contacts with the surrounding sediments, and the relative low concentration of dispersed glass particles, the thickness of individual horizons cannot be determined precisely. Based on differences in modal compositions, ash-bearing sediments can be divided into two groups: (1) disseminated ash layers $=10 \%-80 \%$ glass particles (DA in Table 2); and (2) ash-enriched layers $=5 \%-10 \%$ glass particles (EL in Table 2). Altogether, five disseminated ash layers and 16 ashenriched layers were identified in Holes 918A and 918D. In contrast to Site 919 (Lacasse et al., this volume), discrete ash layers with sharp contacts and more than $80 \%$ glass particles were not found at Site 918.

In spite of the excellent recovery $(\sim 100 \%)$ of the 87 -m-thick Pleistocene sequence of Hole 918A, only two Pleistocene ash deposits were identified (Cores 152-918A-9H and 10H). In contrast, 13 ash deposits were found in Cores 152-918A-10H to $33 \mathrm{X}$ in the $245-\mathrm{m}-$ thick Pliocene sequence of Hole 918A (average recovery $=68 \%$ ). Considering biostratigraphic and paleomagnetic data as well as sedimentation rates (Larsen, Saunders, Clift, et al., 1994), this indicates a sedimentation rate of less than 2 ash deposits/m.y. for the Pleistocene, but more than 10 deposits/m.y. for the (late?) Pliocene. These estimates, however, do not take into account a hiatus in the Pleistocene succession corresponding to about 0.8 m.y. (Shipboard Scientific Party, 1994d) and the relatively sparse core recovery in parts of the Pliocene sequence (Fig. 2).

In Hole 918D ash-bearing deposits occur sporadically throughout the $\sim 300$-m-thick sedimentary sequence ranging from lower Pliocene to lower Miocene. Most were found in a depth interval between $~ 570$ and 770 mbsf (Fig. 2) where generally high amounts of volcanogenic components (e.g., pyroxene, zeolite, opaques, etc.) were recorded by the Shipboard Scientific Party (Larsen, Saunders, Clift, et al., 1994). The poor recovery, however, does not permit conclusions on the temporal distribution of Neogene volcanic deposits drilled in Hole 918D.

\section{Texture and Composition}

Dense blocky to slightly vesicular brown glass fragments are the dominant vitric clast type in most ash-bearing sediments recovered at Site 918 (Pl. 1), with some vesicular or pumiceous brown shards occurring in several deposits (e.g., Layers 4, 9, 14, and 20; Pl. 1; Table 2). Only Miocene Layers 19 and 20 contain significant amounts of colorless glass particles (12 vol\% and 70 vol\%, respectively). The majority of these shards are platy or cuspate bubble wall shards; subordinate tubular pumice shards with parallel alignment of elongated vesicles and a few pumice shards with circular vesicles occur in Layer 20 (Pl. 2). Most layers also contain opaque tachylite clasts as well as altered and/or hydrated glass particles. The average medium diameter of the glass particles is $30 \pm 20 \mu \mathrm{m}$ (coarse silt). Maximum grain sizes ( $\varnothing 5$ largest particles) vary strongly from less than $20 \mu \mathrm{m}$ to more than $500 \mu \mathrm{m}$ (Table 2), the largest individual glass fragments being up to $1.5 \mathrm{~mm}$ in medium diameter. Sorting of the ash-bearing sediments is poor except for well-sorted Layer 20.

Fresh colorless and brownish glass particle contents range from 5 to $37 \mathrm{vol} \%$, except for Layer 20, which is $79 \mathrm{vol} \%$. Additional major components are tachylite, various amounts of lithic clasts, crystal fragments, organic material, and clay. Feldspar, quartz, and clinopyroxene are the dominant mineral phases, minor mineral components comprising olivine, amphibole, biotite, opaque (magnetite, pyrite), and diagenetic minerals (e.g., glauconite). The minerals vary widely in grain size and are rarely euhedral. Most are broken and occur as small crystal fragments $(<200 \mu \mathrm{m})$. It is generally difficult to decide whether the crystals and crystal fragments represent essential phenocrysts (co-genetic with the glass shards), volcanic xenocrysts, or epiclastic (detrital) particles.

\section{Geochemistry}

Nine ash deposits from Hole 918A and two from Hole 918D were selected for chemical analyses (Tables 3,4). The totals of microprobe analyses of mafic and intermediate glass particles range from 99.4 to $101.0 \mathrm{wt} \%$, whereas those of felsic glass shards range from 94.1 to $94.7 \mathrm{wt} \%$. The low totals in the felsic glass shards are chiefly due to hydration of felsic glasses and/or high initial volatile contents in felsic magmas ranging, for example, from 2 to $7 \mathrm{wt} \% \mathrm{H}_{2} \mathrm{O}$ (e.g., Bitschene et al., 1989). Inter-laboratory standards and selected ash deposits were analyzed on both electron microprobe systems in order to make our analyses comparable with those of the ash deposits from 


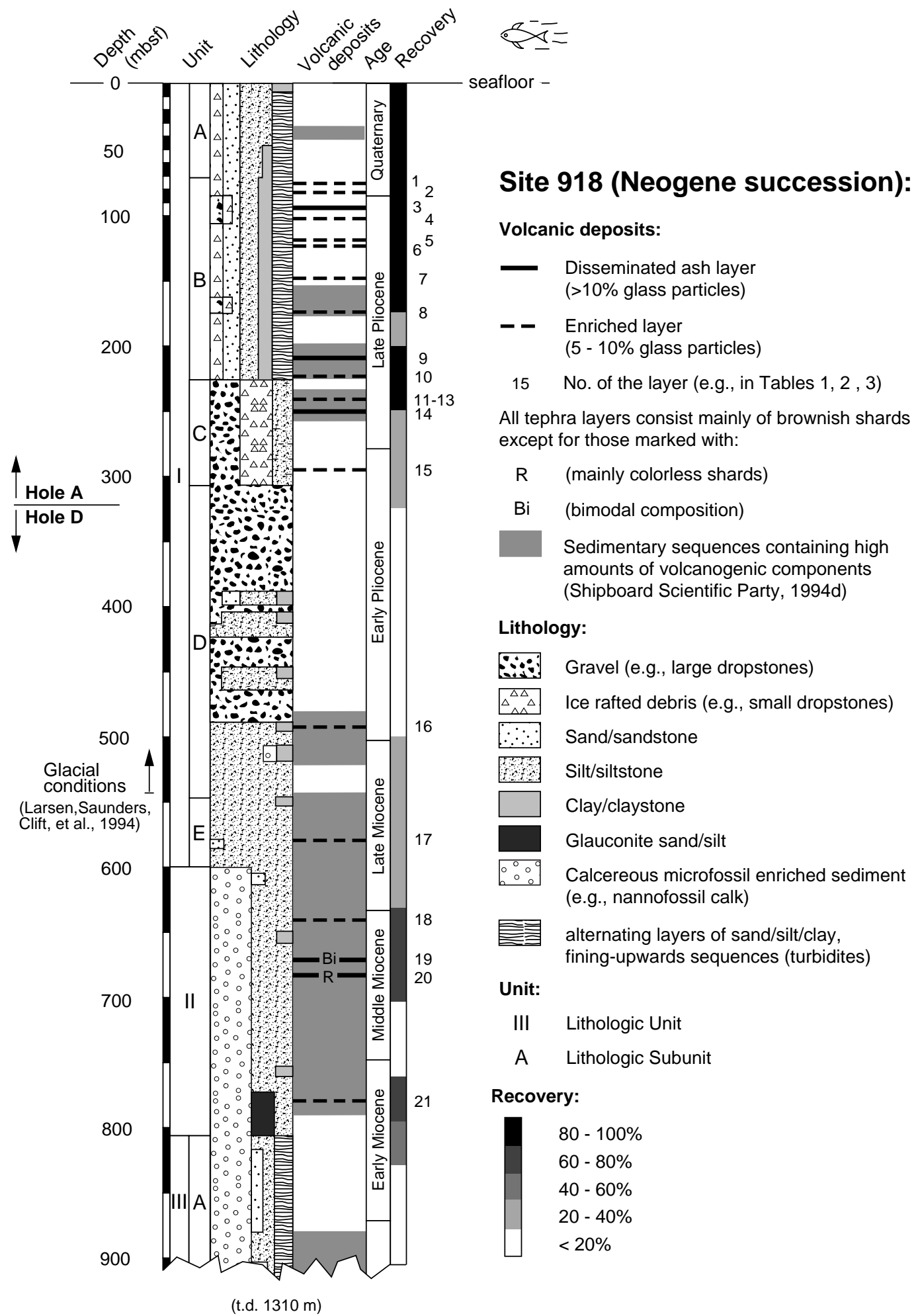

Figure 2. Lithostratigraphy and stratigraphic position of ash-bearing sediments of the Neogene sedimentary sequence recovered at Site 918.

Site 919 presented by Lacasse et al. (this volume). The analytical results match well, particularly for major oxides like $\mathrm{FeO} * \mathrm{CaO}$, and $\mathrm{K}_{2} \mathrm{O}$ (Werner et al., 1996b).

The brownish glass shards generally show basaltic compositions identical to the Icelandic signature; only a few fragments are basaltic andesitic (Fig. 3). The composition of the mafic glass particles is ho- mogeneous in Layers 1 and 9, whereas the glass shards in Layers 10, 15 , and 19 range from primitive to more evolved compositions. Layers $3,5,7$, and 14 show bimodal compositions with two different compositionally homogeneous populations of basaltic shards, and Layers 4 and 20 are compositionally heterogeneous (Table 3). Almost all mafic glass particles belong to the subalkalic and low-K sub- 


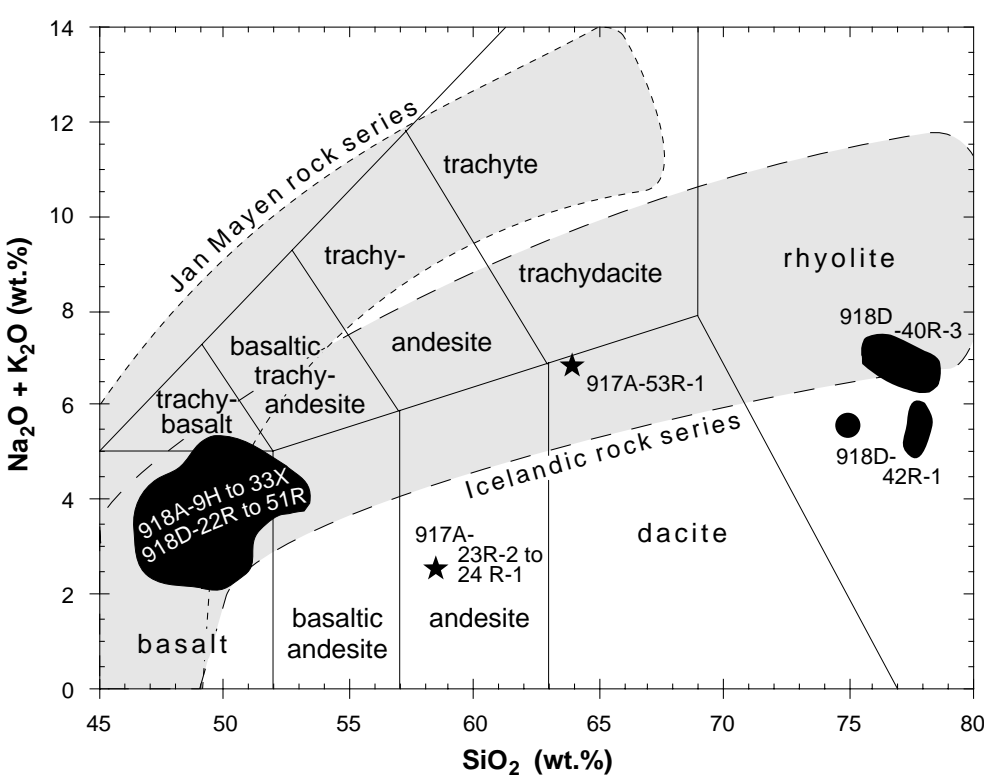

Figure 3. Classification of Neogene glassy tephra (EMP analyses, black fields) and Paleogene volcaniclastic deposits (XRF analyses, black stars) based on total alkali-silica plot (Le Bas et al., 1986). Fields for Jan Mayen rock series (Imsland, 1984), and for Icelandic rock series (Jakobsson, 1979) for comparison. All analyses have been normalized to a volatile free total of $100 \%$. alkalic series. Compositional ranges of mafic glass shards are shown in $\mathrm{MgO}$ variation diagrams (Fig. 4).

The Pleistocene mafic glass particles are mainly low-K subalkalic and form the most primitive tephra recovered at Site 918 . Their $\mathrm{MgO}$ concentrations range from 6.5 to $7.6 \mathrm{wt} \%, \mathrm{TiO}_{2}$ from 1.6 to $2.4 \mathrm{wt} \%$ and $\mathrm{Al}_{2} \mathrm{O}_{3}$ from 13.8 to $14.2 \mathrm{wt} \%$. The Pliocene mafic tephra, in contrast, cover a wider compositional spectrum, $\mathrm{MgO}$ ranging from 3.9 to $7.2 \mathrm{wt} \%$ and $\mathrm{Al}_{2} \mathrm{O}_{3}$ from 12 to $14.4 \mathrm{wt} \%$, and $\mathrm{TiO}_{2}$ contents between 2 and 4 wt\% in most layers. Only a few mafic shard populations in individual deposits can be assigned to high-, medium-, and low-Ti types occurring in the North Atlantic (Bitschene and Schmincke, 1990). Almost all analyses show a positive correlation for $\mathrm{FeO}^{*}, \mathrm{~K}_{2} \mathrm{O}$, and $\mathrm{TiO}_{2}$ vs. $\mathrm{MgO}$ and a negative correlation for $\mathrm{Al}_{2} \mathrm{O}_{3}$ and $\mathrm{CaO}$ vs. $\mathrm{MgO}$ (Fig. 4), following roughly the Thingmuli tholeiitic fractionation trend (Carmichael, 1964). The Miocene mafic glass particles are heterogeneous in composition and cover a similar range as the Pliocene mafic tephra.

The mafic glass particles contain between 100 and $1430 \mathrm{ppm}$ sulfur (Fig. 5A). Sulfur analyses of matrix glasses can be used to assess the degree of degassing of a magma during eruption, if the original sulfur content of the magma is known or can be inferred (e.g., Werner et al., 1996a, 1996b). Moore and Fabbi (1971) estimate the original sulfur content of deep-sea basalts to be $800 \pm 150 \mathrm{ppm}$. According to Moore and Schilling (1973), the sulfur content of undegassed submarine basalts dredged from the Reykjanes Ridge in water depth of more than $200 \mathrm{~m}$ averages $843 \mathrm{ppm}(660-1340 \mathrm{ppm})$, and the sulfur content of undegassed tholeiitic basaltic magmas from Iceland is estimated to be around 1000 ppm (Moore and Calk, 1991; Werner et al., 1996b). Based on these data, the original sulfur content of the Neogene tholeiites recovered at Site 918 is estimated as $1000 \pm 200 \mathrm{ppm}$. Consequently, $60 \%$ of the mafic glass particles analyzed are not significantly degassed with respect to sulfur (Fig. 5A).

Colorless shards recovered at Site 918 are rhyolitic and most of them show an Icelandic affinity (Fig. 3). Only a few shards have slightly lower alkali contents than the Icelandic series, in particular those found in Core 152-918D-42R (Layer 19). Unlike the compositionally heterogeneous shards in layer $19,81 \%$ of the shards from Layer 20 (Core 152-918D-40R) are chemically homogeneous (Fig. 6) with high $\mathrm{SiO}_{2}(77.6-78.0 \mathrm{wt} \%)$ and $\mathrm{CaO}$ (1.2-1.5 wt \%), but low FeO* (1.0-1.4 wt\%) and $\mathrm{Al}_{2} \mathrm{O}_{3}(12.6-12.9 \mathrm{wt} \%)$ concentrations (all values recalculated volatile free). The remaining shards in this layer form a second homogeneous population with significantly higher FeO* (2.8-3.2 wt\%), and lower in $\mathrm{SiO}_{2}$ concentrations. All rhyolitic tephra drilled on Site 918 belong to the low potassium series $\left(\mathrm{K}_{2} \mathrm{O}\right.$ $<3.8 \mathrm{wt} \%$ ) as defined by Sigurdsson and Loebner (1981).

\section{Eruption Processes, Mode of Transport, and Sources}

The predominance of dense blocky glass shards in the mafic tephra deposits (Pl. 1) recovered at Site 918 indicates the tephra to be derived from hydroclastic fragmentation processes (steam explosions, cooling granulation). The eruptive environment of these hydroclastic eruptions (i.e., deep water vs. shallow water, or subglacial vs. subaerial) can be inferred from the sulfur concentrations of the glass shards. High hydrostatic pressure, or great water depth, prevents the escape of volatiles by exsolution from an erupting magma. Significant sulfur degassing starts when the eruptive center is situated in water depths less than $200 \mathrm{~m}$, whereas below $200 \mathrm{~m}$ sulfur content is independent of depth (Moore and Schilling, 1973; Moore and Calk, 1991; Werner et al., 1996b). Taking this into account, the mafic shards studied were erupted in different environments since most layers contain both undegassed and degassed shards (Fig. 5B). This hypothesis is also supported by the occurrence of highly vesicular mafic shards alongside dense blocky fragments (Pl. 1). On the other hand, the glass populations are generally homogeneous in major element composition. They therefore most probably originated from a distinct volcanic event. A frequent change of the eruption environment in the course of a single eruption is a typical feature of emergent submarine and subglacial/sublacustrine volcanoes (Werner et al., 1996b).

Lacasse et al. (this volume) postulate a transport by stratospheric winds or ice rafting for the particles of discrete and disseminated ash layers drilled at Site 919. In contrast, Site 918 shows relatively low glass particle concentrations, high amounts of different lithic clasts and crystal fragments in most ash deposits, poor sorting, and large maximum grain sizes (Table 2), suggesting a transport by turbidity currents or mass flows, although an ice raft origin cannot be completely ruled out for some deposits and/or fragments.

Iceland is the largest subaerial volcanic area in the North Atlantic, well known for subglacial volcanic activity during the Pleistocene and Pliocene, and an important source for tephra layers in the Irminger Basin (Lacasse et al., this volume). The chemical compositions of the different Icelandic volcanic rock series are well known (Walker, 1963; Carmichael, 1964; Imsland, 1978, 1983; Jakobsson, 1979; Meyer et al., 1985; Oskarsson et al., 1982). The northern MidAtlantic Ridge (MAR), in particular the Reykjanes Ridge, is another possible source region for mafic tephra drilled at Site 918. Basaltic 

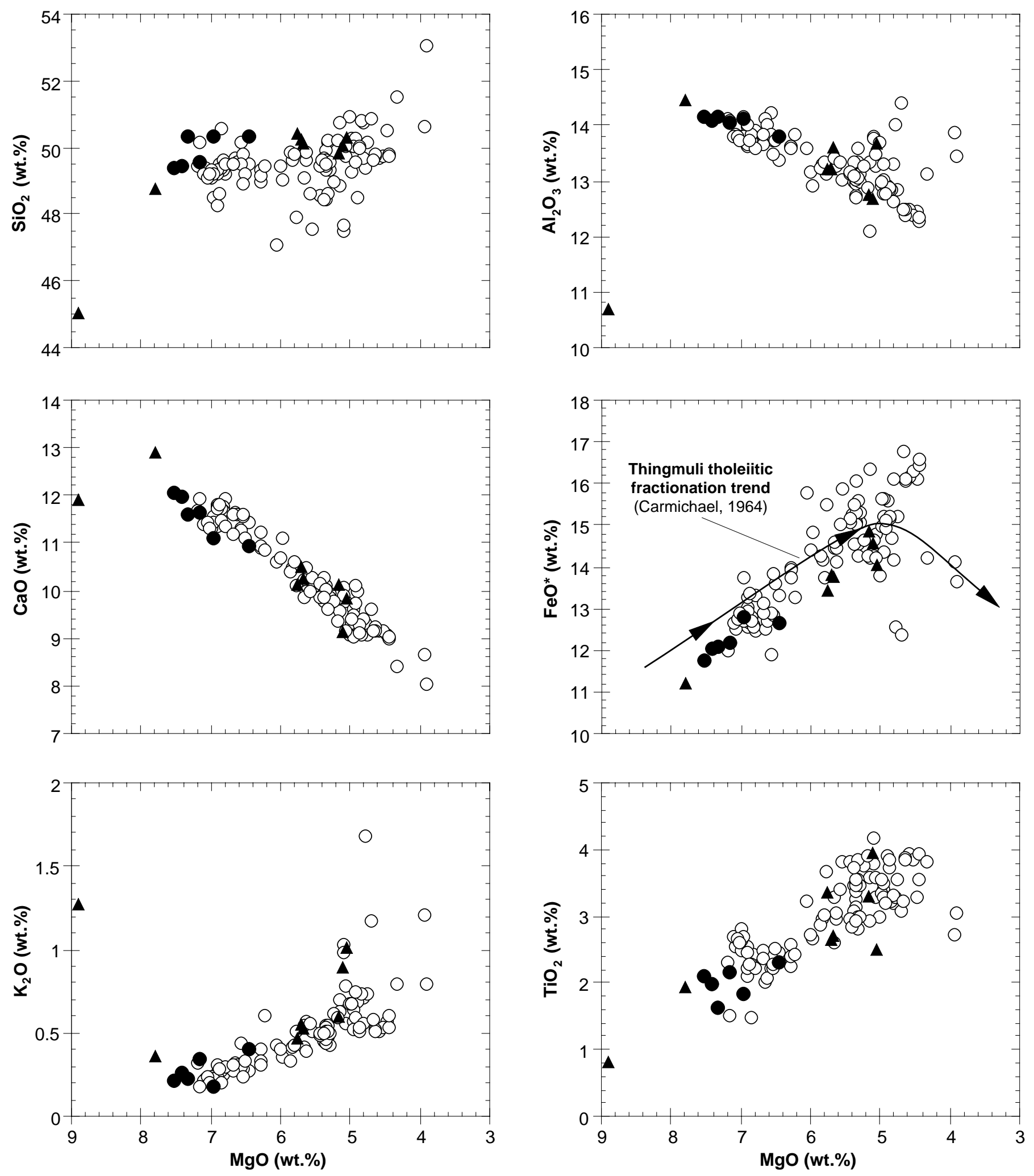

Figure 4. $\mathrm{MgO}$ variation diagrams showing the major element composition $\left(\mathrm{SiO}_{2}, \mathrm{Al}_{2} \mathrm{O}_{3}, \mathrm{CaO}, \mathrm{FeO}, \mathrm{K}_{2} \mathrm{O}, \mathrm{TiO}_{2}\right)$ of mafic glass particles recovered at $\mathrm{Site} 918$. Solid circles $=$ Pleistocene series $($ Cores 152-918A-9H and 10H), open circles $=$ Pliocene series $($ Cores 152-918A-11H through 33X and Core 152-918D-22R), and solid triangles $=$ Miocene series (Cores 152-918D-31R through 51R). All analyses have been normalized to a volatile free total of $100 \%$. 


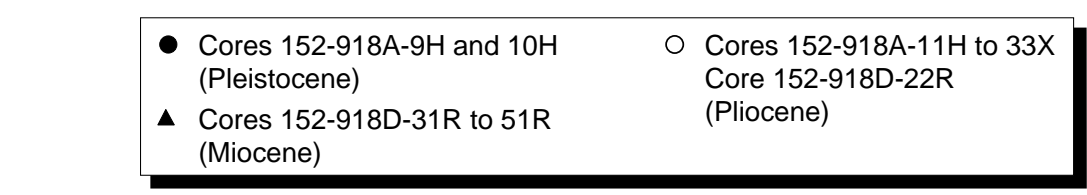

A

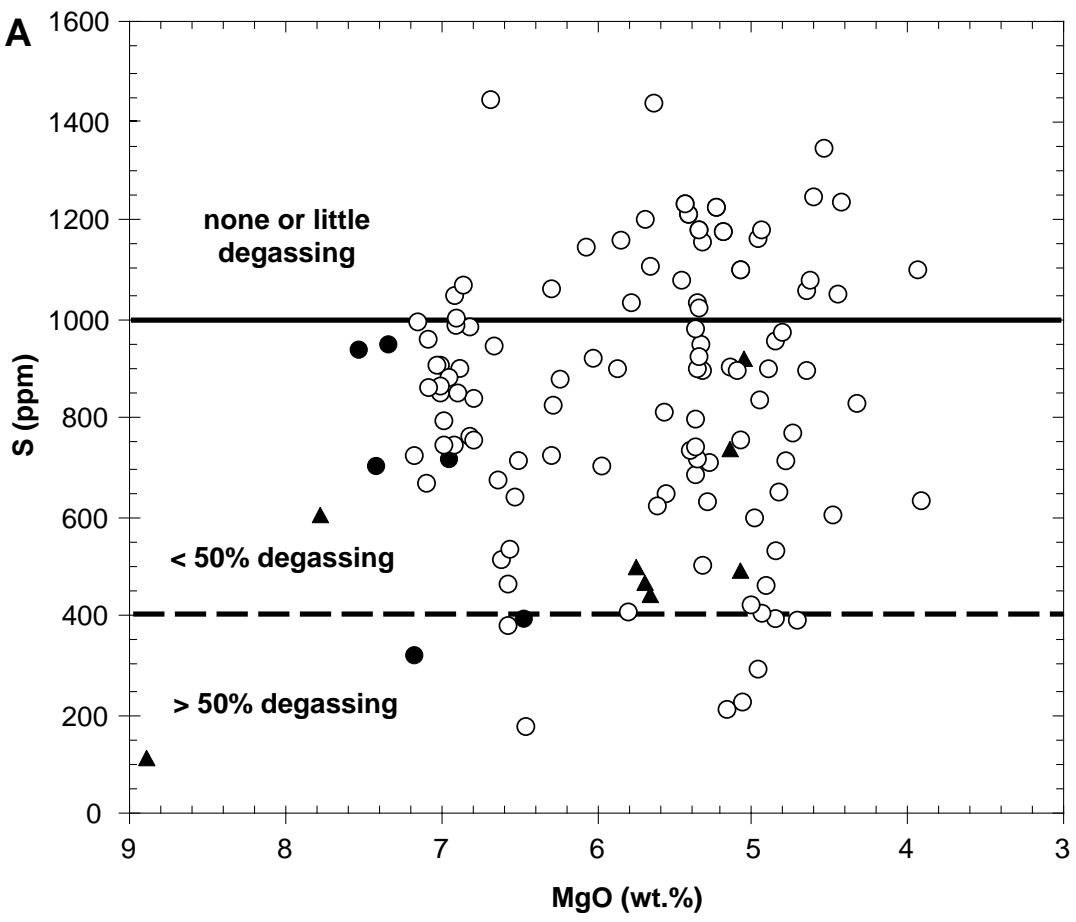

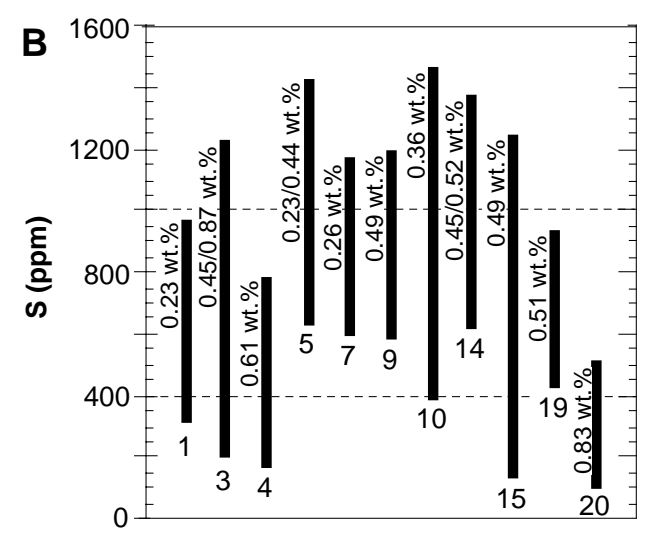

Layer no. incl. average $\mathrm{K}_{2} \mathrm{O}$ (wt.\%)

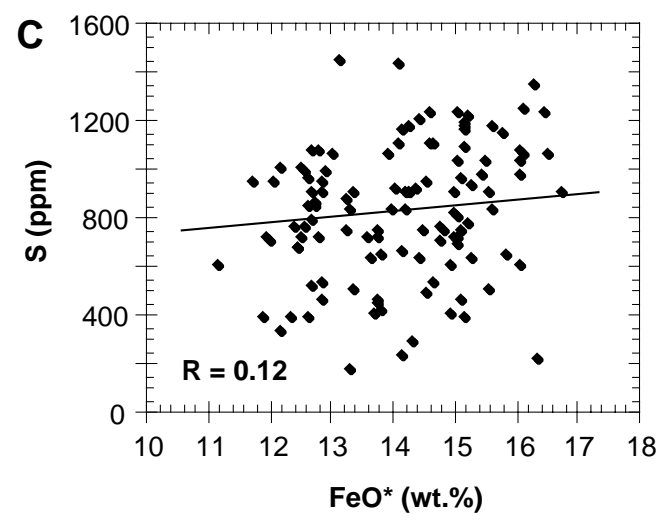

Figure 5. A. Sulfur concentrations of mafic glass particles recovered at Site 918. The degree of degassing is evaluated on the basis of an average original sulfur content of approximately 800-1000 ppm (inferred from data of Moore and Fabbi, 1971; Moore and Schilling, 1973; Moore and Calk, 1991; Werner et al., 1996a). B. Variability of sulfur concentrations of glass particles within individual layers. $\mathrm{K}_{2} \mathrm{O}$ content is also listed for each layer. C. Sulfur vs. FeO* concentrations for mafic glass particles at Site 918. The solid line is a linear regression through the data. Note the lack of correlation between $\mathrm{S}$ and $\mathrm{FeO} *$ in these glasses.

glass fragments on mid-ocean ridges are produced by cooling granulation in deep-water conditions. The chemical composition of MAR basalts is given, for example, by Sigurdsson (1981), Schilling et al. (1983), Lackschewitz and Wallrabe-Adams (1991), and Lackschewitz et al. (1994).

An important feature of MAR-basalts north of the Gibbs-Fracture-Zone $\left(54^{\circ} \mathrm{N}\right)$ and south of Iceland $\left(64^{\circ} \mathrm{N}\right)$ is their low potassium content, with an upper limit of approximately $0.2 \mathrm{wt} \%$. All mafic glass particles recovered at Site 918 show a clear Icelandic affinity in the total alkali-silica diagram (Fig. 3). Moreover, the chemical composition of most Pliocene and Miocene glasses is remarkably similar to the mafic products of the Icelandic Tertiary central volcanoes (Figs. 4, 7). The Reykjanes Ridge is not a likely source for majority of the mafic tephra at Site 918 because their potassium contents generally exceed $0.2 \mathrm{wt} \%$ (Fig. 7A), even if they contain mainly undegassed and dense blocky fragments. Only some mafic glass particles of Layers 5 and 7 have low potassium concentrations (average $=0.23$ and $0.26 \mathrm{wt} \%$, respectively), and are generally undegassed with regard to sulfur. These layers consist only of dense blocky glass fragments and, therefore, may originate from the Reykjanes Ridge.

The majority of the Neogene mafic glass particles recovered at Site 918 are therefore attributed to (probably subglacial) eruptions in Iceland. The deposition of the particles far from Iceland $(\sim 750 \mathrm{~km})$ in the northwestern part of the Irminger Basin may be caused initially by turbidity currents that originated from the Iceland shelf and are related to catastrophic floods ("jökulhlaups"; Carey, pers. comm., 1994) that resulted from subglacial eruptions in northwestern Iceland.
The middle Miocene rhyolitic tephra Layer 20 is well sorted and consists mainly of bubble wall shards and subordinately of small pumice fragments (Pl. 1) derived from magmatic vesiculation and pyroclastic fragmentation. The deposit is therefore interpreted as distal fallout tephra from a high eruption column of a Plinian eruption. This hypothesis is also supported by the lack of (dense) crystals and the relatively small grain size of the shards $(<<100 \mu \mathrm{m})$. Possible sources for middle Miocene rhyolite tephra are Iceland (Sigurdsson and Loebner, 1981), the Jan Mayen magmatic province (Bitschene et al., 1989), and volcanic centers near the Iceland-Faeroe Ridge (Sigurdsson and Loebner, 1981). Jan Mayen and the Iceland-Faeroe Ridge, however, produced high-K alkali rhyolites and therefore can be excluded as a source for the low-K rhyolitic tephra of Layer 20. The major element composition of its glass shards indicate that Layer 20 was derived from explosive eruptions of an early Icelandic central volcano (Fig. 7A). The two chemically different populations of rhyolitic glass shards in this layer probably reflect the eruption from a compositionally zoned or mixed magma column.

\section{PALEOGENE VOLCANICLASTIC DEPOSITS}

The lithology of the Paleogene sequence drilled during Leg 152 is shown in Figure 8. Apart from a slightly altered upper Oligocene ash deposit on top of Subunit IIIB, Paleogene volcaniclastic layers were found in Hole 918D below 1117.8 mbsf in Units IV and V, and intercalated with the flood basalts. In Hole 917A several Paleogene successions of volcaniclastic layers occur just overlying the flood basalts 

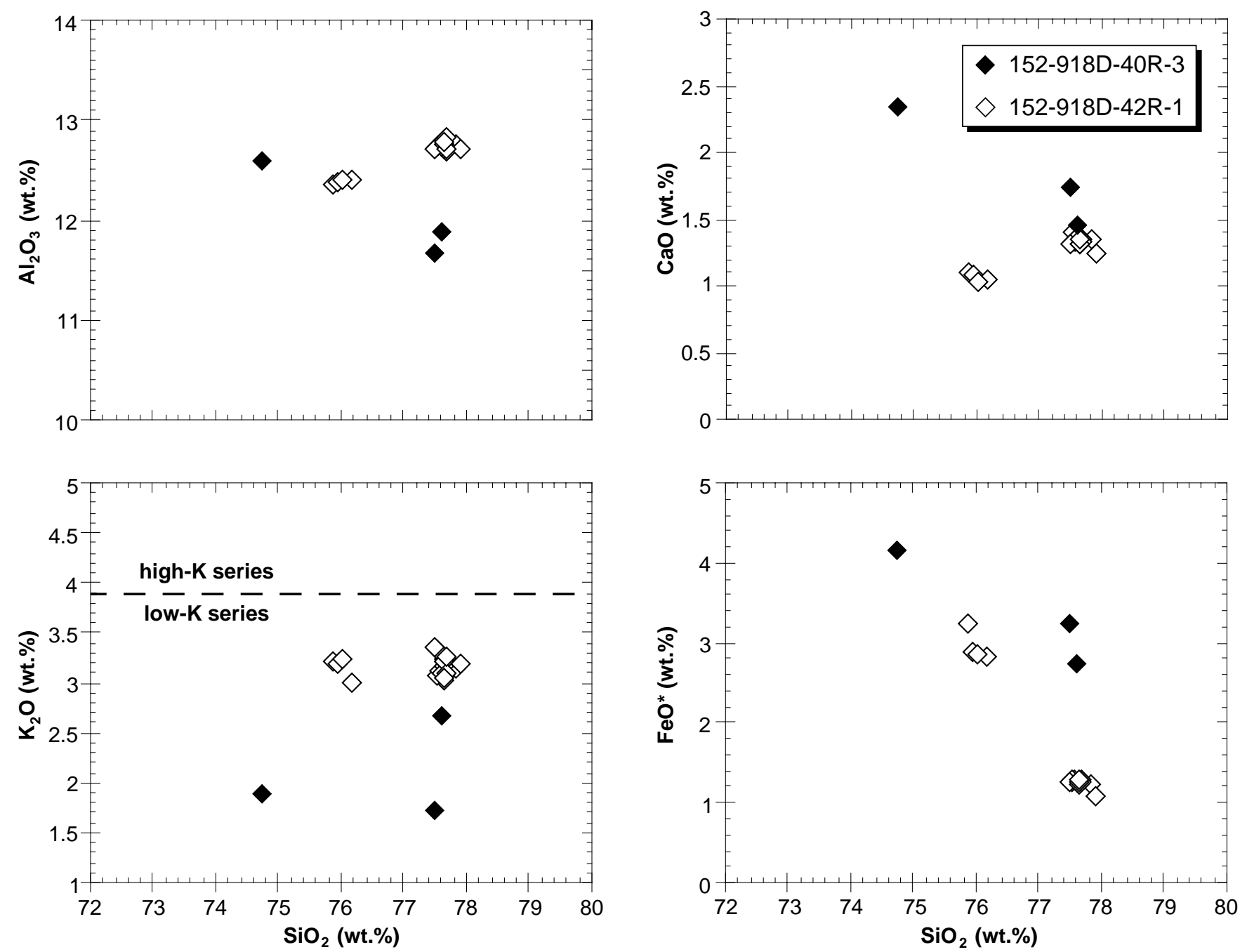

Figure 6. $\mathrm{SiO}_{2}$ variation diagrams showing the major element composition $\left(\mathrm{Al}_{2} \mathrm{O}_{3}, \mathrm{CaO}, \mathrm{FeO} *, \mathrm{~K}_{2} \mathrm{O}\right)$ and subdivision in low- $\mathrm{K}$ and high- $\mathrm{K}$ series (after Sigurdsson and Loebner, 1981) of rhyolitic glass particles recovered at Site 918. All analyses have been normalized to a volatile free total of $100 \%$.

in lithologic Unit II and within the flood basalt sequence (Fig. 8). A few thin Paleogene volcaniclastic deposits were also recovered in Holes 915A and 916A (Table 1; Fig. 8).

The Paleogene volcaniclastic deposits occur as highly altered ash layers, tuffs, lapillistones, monomict and polymict breccias, as well as polymict conglomerates. Other major volcaniclastic deposits, which are not considered in this study, comprise fluvial deposits consisting mainly of volcanogenic material (e.g., within the flood basalts in Section 152-917A-22R-1; Shipboard Scientific Party, 1994b) and a succession of metamorphosed tuffaceous metasediments beneath the basalt sequence at Site 917 (Vallier et al., this volume).

\section{Ash Layers}

At least six disseminated or discrete ash layers were identified in Sections 152-918D-88R-1 to 89R-4 (lithologic Unit IV, middle Eocene) within a sequence of siltstone and silty nannofossil chalk. These 2- to 15-cm-thick layers consist of slightly to highly altered mafic glass fragments in a clay matrix, and subordinate crushed pumice occurs in some layers. Additional major constituents are crystal fragments, basaltic clasts, glauconite, and organic material. The mafic shards are mainly dense, their average medium diameter ranging from 40 to $200 \mu \mathrm{m}$. In addition, several layers with minor contents of altered mafic shards occur in the same interval. Some of these deposits are dominated by glaucony nodules that may represent argillized basaltic glass fragments (Jeans et al., 1982). Deeper in the sequence, in lithologic Unit V (lower Eocene), only a few sedimentary deposits show clear evidence for a volcanogenic origin (e.g., slightly altered mafic shards, crushed pumice fragments, and zeolites), but abundant clay aggregates and glaucony nodules in some deposits may represent completely altered tephra.

Using piston and Deep Sea Drilling Project (DSDP) cores, Donn and Ninkovich (1980) inferred a middle Eocene episode of abundant volcanism in the North Atlantic, the main volcanic source area being the subaerial Iceland-Faeroes ridge (Sigurdsson and Loebner, 1981). The relatively high amount of middle Eocene ash layers in Unit IV probably reflects this peak in volcanic activity.

\section{Volcanic Breccias and Conglomerates}

The terms volcanic breccia and volcanic conglomerate refer to poorly sorted deposits consisting predominantly of volcanogenic clasts (e.g., basaltic rock fragments) in a fine-grained matrix (Shipboard Scientific Party, 1994a). Those deposits are present in cores recovered just overlying the flood basalt sequence (lithologic Unit III) at Sites 915, 916, and 917 (A in Fig. 8), as well as intercalated in the 


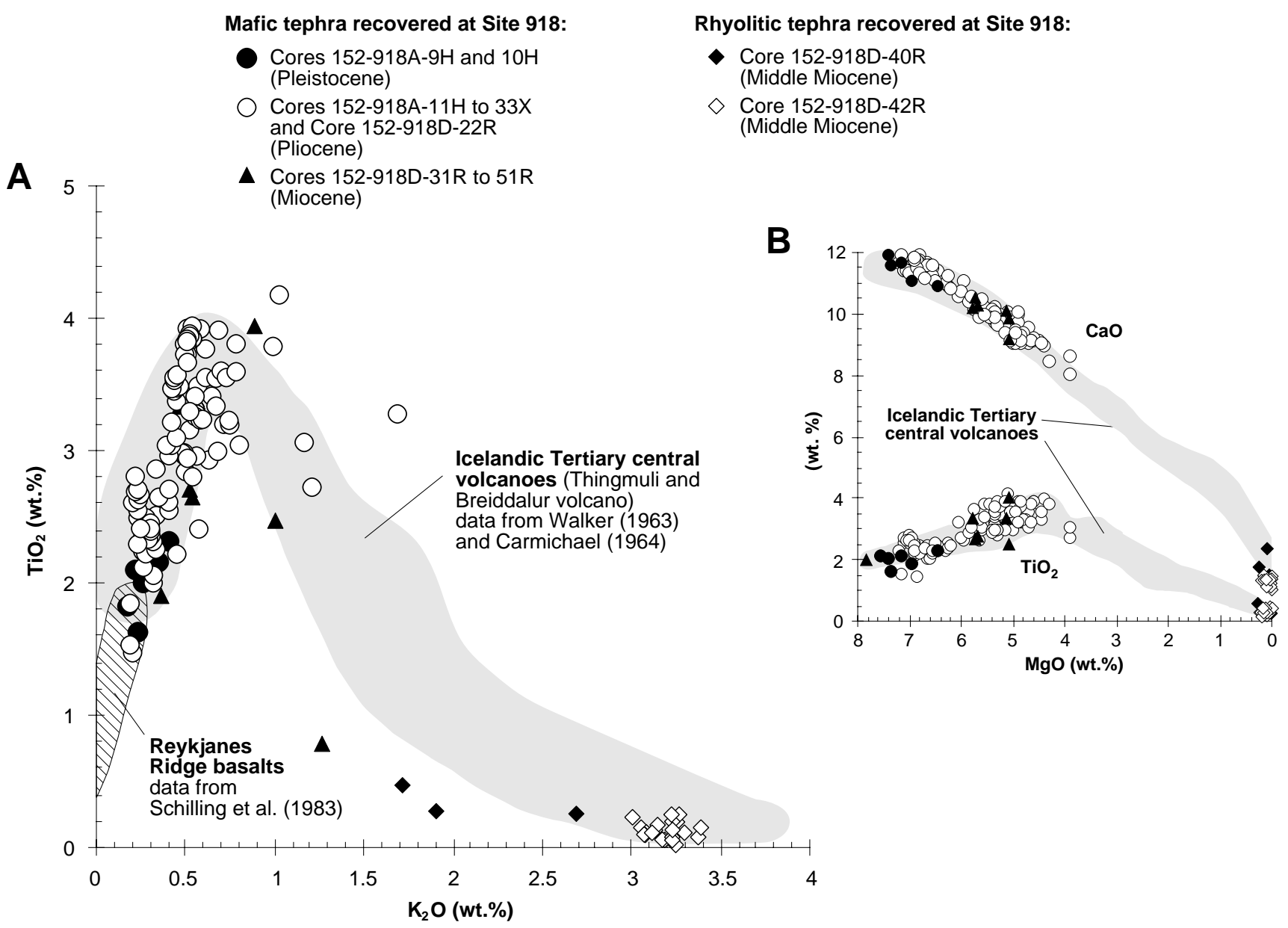

Figure 7. A. $\mathrm{TiO}_{2}$ vs. $\mathrm{K}_{2} \mathrm{O}$ concentrations of rhyolitic and basaltic glass particles recovered at Site 918 and reference fields for Tertiary Icelandic central volcanoes and Reykjanes Ridge basalts. B. $\mathrm{CaO}$ and $\mathrm{TiO}_{2}$ vs. $\mathrm{MgO}$ concentrations of rhyolitic and basaltic series recovered at Site 918 and reference fields for Tertiary Icelandic central volcanoes.

flood basalts at Sites 917 and 918 . The latter are generally monomict breccias directly associated with individual lava flows (e.g., top or basal breccias; Shipboard Scientific Party, 1994c, 1994d).

At Site 917, a 6-cm-thick sequence of a calcite-cemented, polymict volcanic conglomerate was recovered on top of lithologic Unit III (interval 152-917A-6R-1, 0-6 cm). Similar conglomerates were found at Sites 915 (interval 152-915A-23R-1, 0-121 cm) and 916 (interval 152-916A-15R-2, $0-10 \mathrm{~cm}$ ). These are underlain by polymict volcanic breccias (interval 152-915A-23R-2, 7-70 cm, and intervals 152-916A-15R-1, 0-33 cm; 15R-2, 46-150 cm; 15R-3, 0$47 \mathrm{~cm}$ ) overlying the lava succession (Fig. 8). The clasts (up to $30 \mathrm{~cm}$ diameter) of both breccia and conglomerate are mainly basaltic lava fragments varying in mineral content, texture, vesicularity, and degree of alteration. Most deposits are matrix-supported, although some breccias show a crude normal grading. The major constituents of the matrix of the conglomerates are feldspar, quartz, pyroxene, biotite, amphibole, glauconite, calcite, small clasts of basalt, and slightly to highly altered volcanic glass. The glass particles are mainly dense or vesicular brownish or greenish shards; crushed pumice fragments are rare. The feldspars comprise compositionally different types of plagioclase, as well as alkali feldspar in some deposits (Fig. 9). In addition, the matrix of the breccias contains abundant opaques and clay material, but usually neither quartz nor alkali feldspar.

The structure and polymict character of the breccias and conglomerates indicate an epiclastic origin of these deposits. High amounts of volcanogenic components, abundant clay-sized material, poor sorting, and grading indicate that the breccias are polymict lahars. The conglomerates are interpreted as fluviatile deposits (Shipboard Scientific Party, 1994b).

The succession of lahars and fluviatile deposits probably reflects the transition from an active volcanic stage to a nonvolcanic erosional stage of the source area (East Greenland). Polymict lahars are not directly initiated by volcanic eruptions but may be caused by collapse of crater walls or avalanching of rain-soaked debris covering steep slopes (Fisher and Schmincke, 1984). They therefore probably mark the first stage of erosion after the volcanic activity ceased. The subsequent stage is represented by the fluviatile deposits. The high amounts of quartz and alkali feldspar found in these deposits may reflect the beginning of deep erosion of the crystalline basement (e.g., granite, syenite). This hypothesis corresponds well to the successive increase in quartz and the decrease in volcanogenic components in the overlying sediments (lithologic Units II and I), which is attributed to a change of the sedimentary input to the East Greenland Shelf from a volcanic source to a crystalline source (Shipboard Scientific Party, 1994b).

\section{Lapillistones and Tuffs}

Lapillistones and tuffs were recovered at Site 917 intercalated within the Middle Series of the flood basalts in igneous Units 35 and 
East GreenIand Shelf

I r m inger B as in

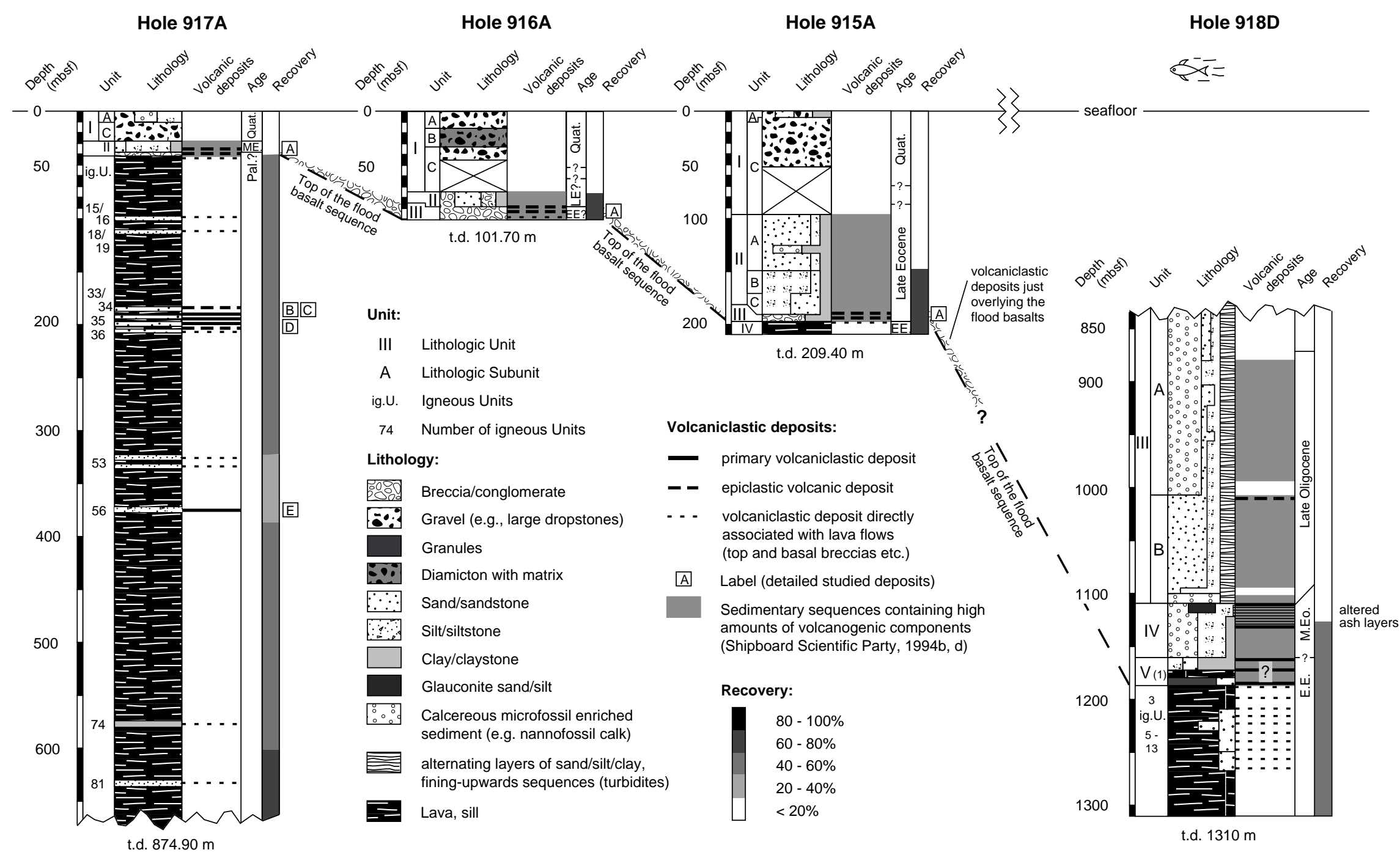

Figure 8. Lithostratigraphy and stratigraphic distribution of Paleogene volcaniclastic deposits recovered on the East Greenland Shelf (Sites 915-917) and on the continental rise of southeast Greenland (Irminger Basin, Site 918). 


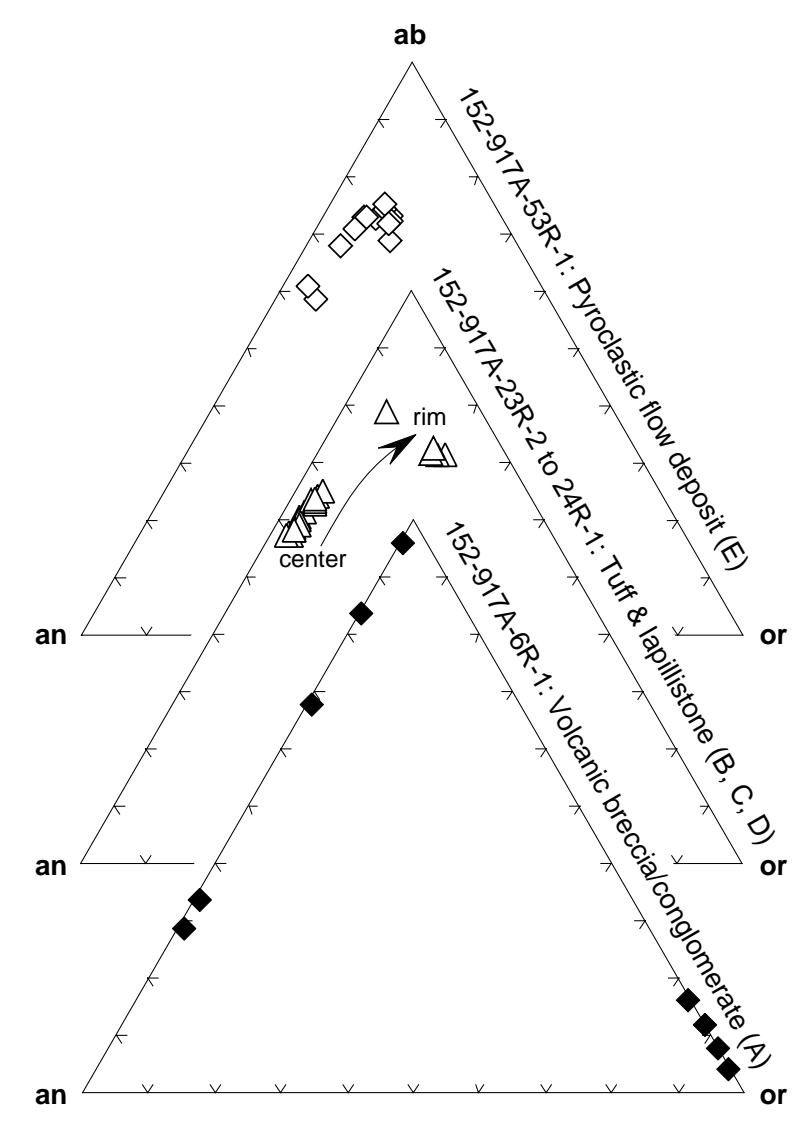

Figure 9. Composition of feldspars in selected Paleogene volcaniclastic deposits recovered at Site 917.

56 (Fig. 8). The complex volcaniclastic succession of Unit 35 comprises, from top to bottom, $18 \mathrm{~cm}$ reddish tuff (B in Fig. 8; interval 152-917A-23R-2, 120-138 cm), $42 \mathrm{~cm}$ lapillistone (C; 152-917A23R-3, 0-43 cm), $5 \mathrm{~cm}$ dark reddish soil (152-917A-23R-2, 42-47 $\mathrm{cm}), 10 \mathrm{~cm}$ thick tuff (D; 152-917A-24R-1, 0-10 cm), and $1 \mathrm{~m}$ volcanic breccia that grades into the underlying flow top (152-917A$24 \mathrm{R}-1,10-110 \mathrm{~cm})$. The total thickness of this succession is $6.5 \mathrm{~m}$ but, due to the poor recovery $(\sim 30 \%)$, the true thickness of the deposits is unclear. Unit 56 consists of $115 \mathrm{~cm}$ of massive, dark reddish brown tuff (E; interval 152-917A-53R-1, 0-115 cm). Four selected deposits $(\mathrm{B}, \mathrm{C}, \mathrm{D}$, and $\mathrm{E})$ were studied in more detail:

The reddish tuff (B) shows parallel layering with laminae 1-5 mm thick. Major constituents are crystal fragments and large lithic clasts up to $1 \mathrm{~cm}$ in a reddish clay matrix (Pl. 2). Feldspars up to $1 \mathrm{~mm}$ (average $=0.5 \mathrm{~mm})$ in size are the dominant mineral phase $(15 \mathrm{vol} \%)$. Pyroxene (1 vol\%), magnetite, quartz, and chlorite (all <1 vol\%) are minor. The lithic clasts range from rhyolites to andesites and basalts. The lapillistone (C) is massive and, in contrast to the reddish tuff, lithologically homogeneous. The deposit consists of altered broken pumice fragments and feldspars ( $25 \mathrm{vol} \%)$, ortho- and clinopyroxene (1-2 vol\%), and magnetite $(<1$ vol\%). The feldspars occur as euhedral and optically zoned phenocrysts up to $5 \mathrm{~mm}$ (average $1.7 \mathrm{~mm}$ ) in size (Pl. 2). The tuff (D) is finely laminated and also lithologically homogeneous. Large euhedral or broken feldspar phenocrysts (up to 3 $\mathrm{mm}$, average $=1.2 \mathrm{~mm})$ are the dominant mineral phase $(5-10 \mathrm{vol} \%)$ in a dense devitrified matrix (Pl. 2). Minor mineral phases are quartz and ore minerals (both $<<1 \mathrm{vol} \%$ ).

The XRF bulk rock analyses of these deposits (Table 5) have to be evaluated with caution, because of crystal/glass sorting and contamination processes prior to and during deposition and subsequent alteration. Volatile-free normalized bulk rock analyses of the deposits $\mathrm{B}, \mathrm{C}$, and $\mathrm{D}$ show a homogeneous andesitic composition in the total alkali silica diagram (Fig. 3). Their uniform concentrations in most immobile elements like Y (35-39 ppm), Zr (468-502 ppm), or $\mathrm{Nb}$ (12-16 ppm) and feldspar compositions (Fig. 9) suggest similar primary chemical composition of these deposits.

Whereas the massive lapillistone $\mathrm{C}$ may have formed by fallout from a pyroclastic eruption, the distinct lamination of the tuffs $B$ and D suggests abundant water (vapor) in the transport system. The crystal fragments and abundance of lithic clasts, which are lithologically different from the essential components, are evidence for sudden steam generation within the country rock and spalling during the eruption of tuff B (Fisher and Schmincke, 1984). This deposit may be derived from hydroclastic eruptions (i.e., steam explosions) and has been probably reworked by water (river or beach). The lithologic homogeneous tuff $\mathrm{D}$, however, probably represents a primary fallout deposit, or pyroclastic flow deposit.

The massive tuff (E) in Unit 56 consists of submicroscopic black to dark reddish material and rare euhedral to subhedral crystals $(<1$ vol\%), which do not exceed $1.5 \mathrm{~mm}$ in size. Its crystal fraction consists chiefly of albite-rich plagioclase phenocrysts (Fig. 9), with minor pyroxene, quartz and ore minerals. The tuff has a dacitic composition (Fig. 3; Table 5). Because of its distinct eutaxitic textures, it is interpreted as a partially welded pyroclastic flow deposit (Shipboard Scientific Party, 1994c).

\section{Age Determinations}

A first series of feldspar crystals (CANS 8 and 10) was handpicked from Samples 152-917A-23R-2, 127-131 cm (tuff B); 23R-3, 14-17 cm (lapillistone C); 24R-1, 1-3 cm (tuff D1); and 24R-1, 6-8 $\mathrm{cm}$ (tuff D2), and cleaned ultrasonically. Following, the laser dating results are discussed in terms of apparent ages, isotope correlation, and compositional criteria derived from neutron reactions on calcium $\left(\mathrm{Ca} / \mathrm{K}\right.$ ratios derived from ${ }^{37} \mathrm{Ar}_{\mathrm{Ca}}{ }^{139} \mathrm{Ar}_{\mathrm{K}}$ ), and potassium (volume ${ }^{39} \mathrm{Ar}_{\mathrm{K}}$ released per unit mass during laser fusion). All errors are quoted at the one sigma level (Table 6).

Five feldspar crystals from sample D1, ranging in mass from 0.05 to $0.23 \mathrm{mg}$, yield apparent ages ranging from $56.7 \pm 0.3 \mathrm{Ma}$ to $77 \pm 1$ Ma. Potassium contents $\left(\mathrm{cm}^{3} \mathrm{STP}{ }^{39} \mathrm{Ar} / \mathrm{mg} ; 1.0 \times 10^{-10}\right.$ to $\left.1.4 \times 10^{-10}\right)$ and $\mathrm{Ca} / \mathrm{K}$ ratios $(0.5-0.9)$ are typical for anorthoclase. Both vary only slightly, except for crystal D1-b (77 $\pm 1 \mathrm{Ma})$ which shows a significantly lower ${ }^{39} \mathrm{Ar}$ release $\left(0.5 \times 10^{-10} \mathrm{~cm}^{3} \mathrm{STP} / \mathrm{mg}\right)$, higher $\mathrm{Ca} / \mathrm{K}$ ratio (1.3) and atmospheric ${ }^{40} \mathrm{Ar}$ contamination (79\%) (andesine?). Isotope correlation returns an "errorchron" age of $59 \pm 3$ Ma with an initial ${ }^{40} \mathrm{Ar} /{ }^{36} \mathrm{Ar}$ ratio of $300 \pm 13$ (mean square weighted deviation [MSWD] = 172). The MSWD is not significantly reduced if crystal D1-b is excluded from the calculations.

Apparent ages of nine anorthoclase feldspars from sample D2 $(0.2-0.6 \mathrm{mg}$ ) range from $60.9 \pm 0.2 \mathrm{Ma}$ to $64.3 \pm 0.2 \mathrm{Ma}$. Potassium contents $\left(1.0 \times 10^{-10}\right.$ to $\left.1.5 \times 10^{-10} \mathrm{~cm}^{3} \mathrm{STP}{ }^{39} \mathrm{Ar} / \mathrm{mg}\right)$ and $\mathrm{Ca} / \mathrm{K}$ ratios $(0.5-1.2)$ are similar to D1, but atmospheric ${ }^{40} \mathrm{Ar}$ contents are significantly lower $(0.5 \%-4.4 \%)$. The entire population defines an "errorchron" with an age of $60.6 \pm 0.4 \mathrm{Ma}$ and an initial ${ }^{40} \mathrm{Ar} /{ }^{36} \mathrm{Ar}$ ratio of $674 \pm 93$ (MSWD = 12).

Feldspar crystals from sample C (0.08-0.24 mg) show apparent ages from $37 \pm 2 \mathrm{Ma}$ to $57.7 \pm 0.7 \mathrm{Ma}$. The sample consists exclusively of plagioclase (andesine), thus potassium contents are uniformly low $\left(0.2 \times 10^{-10}\right.$ to $\left.0.3 \times 10^{-10} \mathrm{~cm}^{3} \mathrm{STP}^{39} \mathrm{Ar} / \mathrm{mg}\right)$ and $\mathrm{Ca} / \mathrm{K} \mathrm{ra}-$ tios are uniformly high (6.9-12.4). Atmospheric ${ }^{40} \mathrm{Ar}$ contamination is generally high too (78-94\%), except for one crystal $(\mathrm{C}-\mathrm{a}=3.6 \%)$, which also shows the highest apparent age of the population (57.7 \pm $0.7 \mathrm{Ma}$ ). Isotope correlation gives an "errorchron" with an age of 57 $\pm 3 \mathrm{Ma}$ and an initial ${ }^{40} \mathrm{Ar} /{ }^{36} \mathrm{Ar}$ ratio of $287 \pm 5(\mathrm{MSWD}=36)$.

Eight feldspar crystals $(0.09-0.30 \mathrm{mg})$ were analyzed from sample B. The sample shows a pronounced bimodal composition. Half of 
Table 5. Bulk rock analyses (XRF) of Paleogene volcaniclastic deposits recovered intercalated within the flood basalt succession at Site 917.

\begin{tabular}{|c|c|c|c|c|c|}
\hline $\begin{array}{l}\text { Core, section: } \\
\text { Interval }(\mathrm{cm}) \text { : } \\
\text { Label: } \\
\text { Type: }\end{array}$ & $\begin{array}{c}\text { 152-917A-23R-2 } \\
127-131 \\
\text { B } \\
\text { Tuff }\end{array}$ & $\begin{array}{c}\text { 152-917A-23R-3 } \\
\text { 14-17 } \\
\text { C } \\
\text { Lapillistone }\end{array}$ & $\begin{array}{c}\text { 152-917A-24R-1 } \\
\text { 6-8 } \\
\text { D2 } \\
\text { Crystal tuff }\end{array}$ & $\begin{array}{c}\text { 152-917A-53R-1 } \\
\text { 10-14 } \\
\text { E1 } \\
\text { Pyrocl. flow dep. }\end{array}$ & $\begin{array}{c}\text { 152-917A-53R-1 } \\
\text { 80-83 } \\
\text { E2 } \\
\text { Pyrocl. flow dep. }\end{array}$ \\
\hline $\mathrm{SiO}_{2}$ & 53.22 & 47.33 & 52.92 & 61.18 & 63.00 \\
\hline $\mathrm{TiO}_{2}$ & 1.67 & 1.64 & 1.02 & $\begin{array}{l}1.132 \\
1.32\end{array}$ & 1.23 \\
\hline $\mathrm{Al}_{2} \mathrm{O}_{3}$ & 17.74 & $\begin{array}{l}1.04 \\
15.03\end{array}$ & 21.94 & 12.59 & 12.61 \\
\hline $\mathrm{Fe}_{2} \mathrm{O}_{3}$ & 9.22 & 7.46 & 6.50 & 9.17 & 8.40 \\
\hline $\mathrm{MnO}$ & 0.10 & 0.13 & 0.05 & 0.11 & 0.11 \\
\hline $\mathrm{MgO}$ & 2.91 & 3.17 & 1.98 & $\begin{array}{l}1.52 \\
\end{array}$ & 1.51 \\
\hline $\mathrm{CaO}$ & 2.58 & 3.89 & $\begin{array}{l}1.63 \\
\text { S }\end{array}$ & 3.90 & 3.78 \\
\hline $\mathrm{Na}_{2} \mathrm{O}$ & 2.32 & 2.37 & 2.40 & 2.43 & 3.61 \\
\hline $\mathrm{K}_{2} \mathrm{O}$ & 1.02 & 0.48 & 0.86 & 3.04 & 3.15 \\
\hline $\mathrm{P}_{2} \mathrm{O}_{5}$ & 0.03 & 0.38 & 0.05 & 0.34 & 0.32 \\
\hline $\mathrm{SO}_{3}$ & $<0.05$ & $<0.05$ & $<0.05$ & $<0.05$ & $<0.05$ \\
\hline $\mathrm{Sc}^{3}$ & 21 & 17 & 13 & 18 & 13 \\
\hline $\mathrm{V}$ & 22 & 72 & 58 & $\begin{array}{l}137 \\
137\end{array}$ & 81 \\
\hline $\mathrm{Cr}$ & 34 & 25 & 23 & $<18$ & 19 \\
\hline Co & 7 & 36 & $<4$ & 34 & 25 \\
\hline $\mathrm{Ni}$ & 22 & 25 & 30 & 21 & 19 \\
\hline $\mathrm{Cu}$ & 64 & 18 & 31 & 48 & 35 \\
\hline $\mathrm{Zn}$ & 121 & 121 & 70 & 126 & 100 \\
\hline $\mathrm{Ga}$ & 32 & 25 & 30 & 21 & 22 \\
\hline As & 15 & $<12$ & $<12$ & $<12$ & $<12$ \\
\hline $\mathrm{Rb}$ & 20 & 7 & 8 & 39 & 44 \\
\hline $\mathrm{Sr}$ & 181 & 302 & 186 & 537 & 382 \\
\hline $\mathrm{Y}$ & 39 & 35 & 39 & 28 & 27 \\
\hline $\mathrm{Zr}$ & 487 & 468 & 502 & 226 & 230 \\
\hline $\mathrm{Nb}$ & 12 & $\begin{array}{r}400 \\
12\end{array}$ & 16 & 8 & 6 \\
\hline Mo & 6 & $<2$ & $\begin{array}{r}10 \\
6\end{array}$ & $\begin{array}{l}8 \\
5\end{array}$ & 4 \\
\hline $\mathrm{Ba}$ & 251 & 210 & 1027 & 1286 & 1125 \\
\hline $\mathrm{Ce}$ & 131 & 104 & 245 & 100 & 85 \\
\hline $\mathrm{Pr}$ & 49 & 43 & 41 & 36 & 41 \\
\hline $\mathrm{Nd}$ & 49 & 39 & 85 & 41 & 38 \\
\hline Sm & 11 & 11 & 15 & 10 & 9 \\
\hline $\mathrm{Pb}$ & 29 & 20 & 25 & 9 & 12 \\
\hline Th & 5 & $<4$ & 10 & $<4$ & $<4$ \\
\hline $\mathrm{U}$ & $<6$ & $<6$ & $<6$ & $<6$ & $<6$ \\
\hline & & 11.17 & 9.87 & 1.03 & 2.47 \\
\hline $\mathrm{CO}_{2}$ & 0.51 & 5.01 & 0.23 & 0.07 & 0.10 \\
\hline Total & 97.12 & 98.20 & 99.71 & 99.05 & 99.43 \\
\hline
\end{tabular}

Table 6. Apparent ages, argon isotope composition, and mass of single feldspar crystals from Paleogene tephra deposits (first series) 152-917A-23R-2, 127-131 cm (B), 152-917A-23R-3, 14-17 cm (C), 152-917A-24R-1, 1-3 cm (D1), and 152-917A-24R-1, 6-8 cm (D2).

\begin{tabular}{|c|c|c|c|c|c|c|c|}
\hline Sample no. & $\begin{array}{l}\text { Apparent age } \\
\text { (yrs) }\end{array}$ & $\begin{array}{l}\text { Error } \\
\text { (yrs) }\end{array}$ & ${ }^{40} \mathrm{Ar}^{*} /{ }^{39} \mathrm{Ar}_{\mathrm{K}}$ & $\%{ }^{40} \mathrm{Ar}_{\mathrm{atm}}$ & $\mathrm{Ca} / \mathrm{K}$ & $\begin{array}{l}\text { Mass } \\
(\mathrm{mg})\end{array}$ & $\begin{array}{c}\text { Volume }{ }^{39} \mathrm{Ar} \\
\left(\mathrm{cm}^{3} \mathrm{STP} / \mathrm{mg}\right)\end{array}$ \\
\hline B-a & $6.06 \mathrm{E}+7$ & $8.23 E+4$ & $3.87 \mathrm{E}+1$ & 1.0 & 0.15 & 0.146 & $2.52 \mathrm{E}-10$ \\
\hline B-b & $5.94 \mathrm{E}+7$ & $1.80 \mathrm{E}+5$ & $3.79 \mathrm{E}+1$ & 29.3 & 0.14 & 0.179 & $2.47 \mathrm{E}-10$ \\
\hline B-c & $5.99 \mathrm{E}+7$ & $9.22 \mathrm{E}+4$ & $3.83 E+1$ & 0.3 & 0.14 & 0.231 & $2.06 \mathrm{E}-10$ \\
\hline B-d & $6.27 \mathrm{E}+7$ & $1.10 \mathrm{E}+6$ & $4.01 \mathrm{E}+1$ & 1.5 & 11.08 & 0.092 & $1.33 \mathrm{E}-11$ \\
\hline B-e & $6.28 \mathrm{E}+7$ & $5.37 \mathrm{E}+5$ & $4.01 \mathrm{E}+1$ & 6.7 & 10.92 & 0.172 & $1.72 \mathrm{E}-11$ \\
\hline B-f & $7.36 \mathrm{E}+7$ & $7.22 E+5$ & $4.71 E+1$ & 3.0 & 8.53 & 0.126 & $1.81 \mathrm{E}-11$ \\
\hline B-g & $6.03 E+7$ & $6.10 \mathrm{E}+4$ & $3.85 \mathrm{E}+1$ & 1.4 & 0.14 & 0.286 & $2.15 \mathrm{E}-10$ \\
\hline B-h & $7.89 \mathrm{E}+7$ & $4.89 \mathrm{E}+5$ & $5.07 \mathrm{E}+1$ & 11.9 & 7.78 & 0.299 & $2.58 \mathrm{E}-11$ \\
\hline $\mathrm{C}-\mathrm{a}$ & $5.77 \mathrm{E}+7$ & $7.43 E+5$ & $3.68 \mathrm{E}+1$ & 3.6 & 12.36 & 0.148 & $2.27 \mathrm{E}-11$ \\
\hline $\mathrm{C}-\mathrm{b}$ & $5.73 E+7$ & $6.78 \mathrm{E}+5$ & $3.65 \mathrm{E}+1$ & 77.6 & 9.51 & 0.227 & $2.31 \mathrm{E}-11$ \\
\hline C-c & $5.27 \mathrm{E}+7$ & $1.33 \mathrm{E}+6$ & $3.36 \mathrm{E}+1$ & 79.9 & 8.79 & 0.126 & $1.94 \mathrm{E}-11$ \\
\hline C-d & $4.05 E+7$ & $1.57 \mathrm{E}+6$ & $2.57 \mathrm{E}+1$ & 89.8 & 6.86 & 0.205 & $3.20 \mathrm{E}-11$ \\
\hline C-e & $4.53 \mathrm{E}+7$ & $1.44 \mathrm{E}+6$ & $2.88 \mathrm{E}+1$ & 81.7 & 10.76 & 0.217 & $2.21 \mathrm{E}-11$ \\
\hline C-f & $4.92 E+7$ & $6.95 E+5$ & $3.13 \mathrm{E}+1$ & 70.1 & 8.79 & 0.239 & $2.54 \mathrm{E}-11$ \\
\hline C-g & $3.71 \mathrm{E}+7$ & $2.35 E+6$ & $2.35 \mathrm{E}+1$ & 94.2 & 7.51 & 0.084 & $2.38 \mathrm{E}-11$ \\
\hline D1-a & $5.99 \mathrm{E}+7$ & $2.69 \mathrm{E}+5$ & $3.82 \mathrm{E}+1$ & 4.0 & 0.49 & 0.052 & $1.35 \mathrm{E}-10$ \\
\hline D1-b & $7.69 \mathrm{E}+7$ & $1.43 \mathrm{E}+6$ & $4.93 \mathrm{E}+1$ & 78.8 & 1.25 & 0.062 & $5.38 \mathrm{E}-11$ \\
\hline D1-c & $6.42 \mathrm{E}+7$ & $3.19 \mathrm{E}+5$ & $4.10 \mathrm{E}+1$ & 53.5 & 0.61 & 0.143 & $9.80 \mathrm{E}-11$ \\
\hline D1-d & $5.73 E+7$ & $3.41 E+5$ & $3.66 \mathrm{E}+1$ & 59.6 & 0.74 & 0.184 & $1.17 \mathrm{E}-10$ \\
\hline D1-e & $5.67 \mathrm{E}+7$ & $2.60 \mathrm{E}+5$ & $3.61 \mathrm{E}+1$ & 59.9 & 0.89 & 0.225 & $1.09 \mathrm{E}-10$ \\
\hline D2-a & $6.43 \mathrm{E}+7$ & $2.25 \mathrm{E}+5$ & $3.56 \mathrm{E}+1$ & 3.7 & 0.71 & 0.604 & $1.11 \mathrm{E}-10$ \\
\hline D2-b & $6.16 \mathrm{E}+7$ & $2.19 \mathrm{E}+5$ & $3.41 \mathrm{E}+1$ & 0.5 & 0.62 & 0.367 & $1.44 \mathrm{E}-10$ \\
\hline D2-c & $6.18 \mathrm{E}+7$ & $2.07 \mathrm{E}+5$ & $3.42 \mathrm{E}+1$ & 1.2 & 0.56 & 0.213 & $1.52 \mathrm{E}-10$ \\
\hline D2-e & $6.21 \mathrm{E}+7$ & $2.24 \mathrm{E}+5$ & $3.44 \mathrm{E}+1$ & 2.5 & 0.64 & 0.337 & $1.39 \mathrm{E}-10$ \\
\hline D2-f & $6.12 E+7$ & $1.67 \mathrm{E}+5$ & $3.38 \mathrm{E}+1$ & 1.0 & 0.60 & 0.358 & $1.42 \mathrm{E}-10$ \\
\hline D2-g & $6.09 \mathrm{E}+7$ & $2.07 \mathrm{E}+5$ & $3.37 \mathrm{E}+1$ & 2.2 & 0.55 & 0.364 & $1.45 \mathrm{E}-10$ \\
\hline D2-h & $6.42 \mathrm{E}+7$ & $2.15 \mathrm{E}+5$ & $3.55 \mathrm{E}+1$ & 4.4 & 1.19 & 0.275 & $1.03 \mathrm{E}-10$ \\
\hline D2-i & $6.14 \mathrm{E}+7$ & $1.88 \mathrm{E}+5$ & $3.40 \mathrm{E}+1$ & 1.2 & 0.59 & 0.565 & $1.01 \mathrm{E}-10$ \\
\hline D2-k & $6.26 \mathrm{E}+7$ & $2.59 \mathrm{E}+5$ & $3.46 \mathrm{E}+1$ & 1.4 & 0.50 & 0.410 & $1.49 \mathrm{E}-10$ \\
\hline
\end{tabular}


the crystals are plagioclase (andesine-oligoclase) with low potassium contents $\left(0.1 \times 10^{-10}\right.$ to $\left.0.3 \times 10^{-10} \mathrm{~cm}^{3} \mathrm{STP}^{39} \mathrm{Ar} / \mathrm{mg}\right)$ and high $\mathrm{Ca} / \mathrm{K}$ ratios (7.8-11.1). These crystals give apparent ages ranging from $62.8 \pm 0.5$ to $78.9 \pm 0.5 \mathrm{Ma}$. The other half represent K-feldspars (anorthoclase?), which show the highest potassium contents in the entire Site 917 sample series $\left(2.2 \times 10^{-10}\right.$ to $2.5 \times 10^{-10} \mathrm{~cm}^{3}$ STP ${ }^{39} \mathrm{Ar} / \mathrm{mg}$; $\mathrm{Ca} / \mathrm{K}$ ratio $=0.14-0.15)$. Their apparent ages range from $59.4 \pm 0.2$ $\mathrm{Ma}$ to $60.6 \pm 0.1 \mathrm{Ma}$. The entire population (plagioclase plus K-feldspar) gives an errorchron age of $60.3 \pm 0.8 \mathrm{Ma}$ (initial ${ }^{40} \mathrm{Ar} /{ }^{36} \mathrm{Ar}=329$ \pm 56 ; MSWD = 367).

In summary, the first series of ${ }^{40} \mathrm{Ar} /{ }^{39} \mathrm{Ar}$ laser ages of feldspar crystals from Site 917 samples D1, D2, C, and B uniformly shows a high degree of scatter that is much beyond the variability that is commonly introduced by analytical errors (MSWD < 3). This scatter is only partly due to primary differences in the composition (and origin, and age?) of the crystals, which are contained as phenocrysts (and older xenocrysts?) in highly altered deposits interpreted to represent primary (D1, D2, C) or reworked (B) tephra. Because the scatter equally affects the weighted mean apparent ages and the isotope correlation, and estimated initial ${ }^{40} \mathrm{Ar} /{ }^{36} \mathrm{Ar}$ ratios are near 295.5, there is also no unambiguous indication of a general "excess" ${ }^{40} \mathrm{Ar}$ component in the crystals. Most likely, the Ar isotope composition of some of the crystals is affected by alteration. All feldspars appeared clean during initial microscopic inspection following a rigid ultrasonic cleaning procedure, but showed pronounced internal discoloration along cleavages or exsolution lamellae after irradiation, possibly indicating the presence of submicroscopic alteration products and/or fluid and glass inclusions. Of course, Ar isotope compositions of crystals with primarily low potassium and ${ }^{40} \mathrm{Ar}_{\text {rad }}$ contents (samples B and $\mathrm{C}$ plagioclase) are most strongly affected by alteration-induced exchange of potassium or argon isotopes.

If only crystals with high potassium contents $\left(\mathrm{cm}^{3} \mathrm{STP}{ }^{39} \mathrm{Ar} / \mathrm{mg}\right)$, and low ${ }^{40} \mathrm{Ar}_{\text {atmos }}$ and $\mathrm{Ca} / \mathrm{K}$ ratio are considered (Fig. 10), these subpopulations give mean apparent ages of $59 \pm 2 \mathrm{Ma}(\mathrm{D} 1 ; \mathrm{N}=4), 61.5$ $\pm 0.2 \mathrm{Ma}(\mathrm{D} 2 ; \mathrm{N}=7)$, and $60.3 \pm 0.2 \mathrm{Ma}(\mathrm{B} ; \mathrm{N}=4)$, indicating that the Paleogene volcanics of Cores 152-917A-23R and 24R were deposited during a short time interval between about 60-61 Ma.

A second series of feldspar crystals from the same samples (B, C, D1, and D2) plus one sample of the massive tuff E (Sample 152917A-53R-1, 80-83 cm) was etched in hydrofluoric acid $(10 \%, 15$ minutes) before ultrasonic cleaning, in order to more efficiently remove alteration products (irradiation CAN 13).

Their argon isotope analyses confirm the compositional diversity of B, C, D1, and D2 feldspar crystals, as expressed by their $\mathrm{Ca} / \mathrm{K}$ ratios, potassium contents, and atmospheric ${ }^{40} \mathrm{Ar}$ contents (Fig. 10; Table 7): tuff $\mathrm{B}$ shows a bimodal feldspar population, lapillistone $\mathrm{C}$ feldspars are uniformly low-K plagioclase, samples D1, D2, and tuff $\mathrm{E}$ show intermediate $\mathrm{Ca} / \mathrm{K}$ ratios and high potassium contents.

The additional HF treatment, however, significantly reduced the single crystal scatter (even though 41 crystals were analyzed, as opposed to 29 during the first series) and thus improved the precision and accuracy of the laser ${ }^{40} \mathrm{Ar} /{ }^{39} \mathrm{Ar}$ age determinations. Samples B, C, $\mathrm{D} 1$, and $\mathrm{E}$ feldspars now yield isochronous argon isotope compositions, indicating eruptions at $60.6 \pm 0.2 \mathrm{Ma}(\mathrm{B}), 60.2 \pm 0.2 \mathrm{Ma}(\mathrm{C})$, $60.9 \pm 0.1 \mathrm{Ma}(\mathrm{D} 1)$, and $60.6 \pm 0.8 \mathrm{Ma}$ (E; Fig. 11). Mean apparent ages, calculated based on atmospheric initial ${ }^{40} \mathrm{Ar} /{ }^{36} \mathrm{Ar}$ ratios of 295.5, range from 60.3 $\pm 0.2 \mathrm{Ma}(\mathrm{C})$ to $61.0 \pm 0.1 \mathrm{Ma}(\mathrm{D} 1)$. Mean square weighted deviates of isochron ages and mean apparent ages are $<3$.

Only the 12 feldspar crystals from sample D2 show nonisochronous argon isotope compositions, and apparent ages ranging from 60.5 to $70.2 \mathrm{Ma}$. Six crystals with low apparent ages, however, yield an error-weighted mean apparent age of $60.8 \pm 0.1 \mathrm{Ma}$, similar to the immediately overlying sample D1.

On a one sigma level (68\% confidence) the ${ }^{40} \mathrm{Ar} /{ }^{39} \mathrm{Ar}$ ages of the Paleogene volcanics of Site 917 are not exactly stratiform, even though the isochron or mean apparent ages of all dated units overlap within two sigma error limits (95\% confidence) (Fig. 11). Because tuff B represents a reworked deposit (whose plagioclase crystals are compositionally identical to the lapillistone C), and tuff D appears to be dominated by older xenocrysts, our determination of the time span comprised by the Paleogene volcanic succession of Site 917 is based on the ${ }^{40} \mathrm{Ar} /{ }^{39} \mathrm{Ar}$ ages of deposits $\mathrm{E}$ and $\mathrm{C}$ only, indicating that the entire sedimentary sequence was deposited between $60.5 \pm 0.2 \mathrm{Ma}(\mathrm{E})$ and $60.3 \pm 0.2 \mathrm{Ma}(\mathrm{C})$.

\section{CONCLUSIONS}

1. The majority of mafic tephra deposits recovered at Site 918 probably originated from subglacial/sublacustrine eruptions in Iceland, as indicated by their textural characteristics, and major element and sulfur chemistry. The tephra was transported into the Irminger Basin by turbidity currents that may have been initiated by catastrophic floods ("jökulhlaups") on Iceland. The middle Miocene rhyolitic tephra can be attributed to highly explosive plinian eruptions in Iceland.

2. The high amount of altered ash layers in the middle Eocene sequence of Hole 918D confirms a peak in volcanic activity in the North Atlantic area during this time, as postulated by previous workers.

3. The transition from an active volcanic period to a nonvolcanic erosional stage at East Greenland is reflected by a succession of lahars and fluvial deposits that overlies the flood basalts at Sites 915, 916, and 917. Highly altered volcaniclastic deposits intercalated with the Middle Series of the flood basalt sequence of Hole 917A represent primary or reworked tephra that originated from explosive hydroclastic and pyroclastic eruptions.

4. Argon isotope compositions and ${ }^{40} \mathrm{Ar} /{ }^{39} \mathrm{Ar}$ laser ages of feldspar crystals from Paleogene tephra deposits at Site 917 are highly variable, probably indicating the presence of older reworked volcanic crystals or xenocrysts in two of the deposits (tuff B [Sample 152-917A-23R-2, 127-131 cm] and tuff D [Samples 152-917A-24R-1, 1-3 cm, and 24R-1, 6-8 cm]). Mean apparent ages of isochronous plagioclase and K-feldspar crystals from tuffs and lapillistones recovered in the intervals 152-917A-53R-1, 80-83 cm, and 23R-3, 14-17 cm, however, indicate an eruption of these tephra deposits between $60.5 \pm$ $0.2 \mathrm{Ma}$ and $60.3 \pm 0.2 \mathrm{Ma}$.

\section{ACKNOWLEDGMENTS}

J. Freitag assisted us with the microprobe work, and S. Dorn carried out the grain-size analyses. The manuscript was improved by reviews of S. Carey, A. Saunders, and B. Wathen. To them, the Leg 152 Shipboard Scientific Party, and the crew of the JOIDES Resolution we owe thanks. This study was supported by the Deutsche Forschungsgemeinschaft (Grant Schm250/56-1 to -4).

\section{REFERENCES}

Bitschene, P.R., and Schmincke, H.-U., 1990. Fallout tephra layers: composition and significance. In Heling, D., Rothe, P., Förstner, U., and Stoffers, P. (Eds.), Sediments and Environmental Geochemistry, Heidelberg (Springer), 48-82.

Bitschene, P.R., Schmincke, H.-U., and Viereck, L., 1989. Cenozoic ash layers on the Vøring Plateau (ODP Leg 104). In Eldholm, O., Thiede, J., Taylor, E., et al., Proc. ODP, Sci. Results, 104: College Station, TX (Ocean Drilling Program), 357-366.

Bogaard, P.V.D., 1995. ${ }^{40} \mathrm{Ar} /{ }^{39} \mathrm{Ar}$ ages of sanidine phenocrysts from Laacher See tephra (12.900 yr BP): chronostratigraphic and petrological significance. Earth Planet. Sci. Lett., 133:163-174. 
Bogaard, P.V.D., and Schirnick, C., 1995. ${ }^{40} \mathrm{Ar} /{ }^{39} \mathrm{Ar}$ laser probe ages of Bishop Tuff quartz phenocrysts substantiate long-lived silicic chamber at Long Valley, United States. Geology, 23:759-762.

Carmichael, I.S.E., 1964. The petrology of Thingmuli, a Tertiary volcano in eastern Iceland. J. Petrol., 5:435-460.

Dalrymple, G.B., and Duffield, 1988. High precision ${ }^{40} \mathrm{Ar} /{ }^{39} \mathrm{Ar}$ dating of Oligocene rhyolites from the Mogollon-Datil volcanic field using a continuous laser system. Geophys. Res. Lett., 15:463-466.

Donn, W., and Ninkovich, D., 1980. Rate of Cenozoic explosive volcanism in the North Atlantic Ocean inferred from deep sea cores. J. Geophys. Res., 85:5455-5460.

Fisher, R.V., and Schmincke, H.-U., 1984. Pyroclastic Rocks: New York (Springer-Verlag)

Imsland, P., 1978. The petrology of Iceland: some general remarks. Nordic Volcanol. Inst. Rep., 7808.

, 1983. Iceland and the ocean floor: comparison of chemical characteristics of the magmatic rocks and some volcanic features. Contrib. Mineral. Petrol., 83:31-37.

- 1984. Petrology, mineralogy and evolution of the Jan Mayen magma system. Soc. Scientar. Island., 43.

Jakobsson, S.P., 1979. Petrology of recent basalts of the Eastern Volcanic Zone, Iceland. Act. Natur. Isl., 26.

Jeans, C.V., Merriman, R.J., Mitchell, J.G., and Bland, D.J., 1982. Volcanic clays in the Cretaceous of southern England and northern Ireland. Clay. Miner, 17:125-156.

Lackschewitz, K., Dehn, J., and Wallrabe-Adams, H.-J., 1994. Volcaniclastic sediments from mid-oceanic Kolbeinsey Ridge, north of Iceland: evidence for submarine volcanic fragmentation process. Geology, 22:975978.

Lackschewitz, K.S., and Wallrabe-Adams, H.-J., 1991. Composition and origin of sediments on the mid-oceanic Kolbeinsey Ridge, north of Iceland. Mar. Geol., 101:71-82.

Larsen, H.C., Saunders, A.D., Clift, P.D., et al., 1994. Proc. ODP, Init. Repts., 152: College Station, TX (Ocean Drilling Program).

Le Bas, M.J., Le Maitre, R.W., Streckeisen, A., and Zanettin, B., 1986. A chemical classification of volcanic rocks based on the total alkali-silica diagram. J. Petrol., 27:745-750.

Meyer, P.S., Sigurdsson, H., and Schilling, J.-G., 1985. Petrological and geochemical variations along Iceland's neovolcanic zones. J. Geophys. Res., 90:10043-10072.

Moore, J., and Fabbi, B., 1971. An estimate of the juvenile sulfur content of basalt. Contrib. Mineral. Petrol., 23:118-127.

Moore, J.G., and Calk, L.C., 1991. Degassing and differentiation in subglacial volcanoes, Iceland. J. Volcanol. Geotherm. Res., 46:157-180.

Moore, J.G., and Schilling, J.-G., 1973. Vesicles, water, and sulfur in Reykjanes Ridge basalts. Contrib. Mineral. Petrol., 41:105-118.
Oskarsson, N., Sigvaldason, G.E., and Steinthorsson, S., 1982. A dynamic model of rift zone petrogenesis and the regional petrology of Iceland. $J$. Petrol., 23:28-74.

Samson, S.D., and Alexander, E.C., Jr., 1987. Calibration of the interlaboratory ${ }^{40} \mathrm{Ar} /{ }^{39} \mathrm{Ar}$ dating standard, MMhb-1. Chem. Geol., 66:27-34.

Schilling, J.-G., Zajac, M., Evans, R., Johnston, T., White, W., Devine, J.D., and Kingsley, R., 1983. Petrologic and geochemical variations along the Mid-Atlantic ridge from $29^{\circ} \mathrm{N}$ to $73^{\circ} \mathrm{N}$. Am. J. Sci., 283:510-586.

Shipboard Scientific Party, 1994a. Explanatory notes. In Larsen, H.C., Saunders, A.D., Clift, P.D., et al., Proc. ODP, Init. Repts., 152: College Station, TX (Ocean Drilling Program), 17-39.

1994b. Shelf stratigraphic synthesis. In Larsen, H.C., Saunders, A.D., Clift, P.D., et al., Proc. ODP, Init. Repts., 152: College Station, TX (Ocean Drilling Program), 159-175.

1994c. Site 917. In Larsen, H.C., Saunders, A.D., Clift, P.D., et al., Proc. ODP, Init. Repts., 152: College Station, TX (Ocean Drilling Program), 107-158.

, 1994d. Site 918. In Larsen, H.C., Saunders, A.D., Clift, P.D., et al., Proc. ODP, Init. Repts., 152: College Station, TX (Ocean Drilling Program), 177-256.

Sigurdsson, H., 1981. First-order major element variation in basalt glasses from the Mid-Atlantic Ridge: $29^{\circ} \mathrm{N}$ to $73^{\circ} \mathrm{N}$. J. Geophys. Res., $86: 9483-$ 9502 .

Sigurdsson, H., and Loebner, B., 1981. Deep-sea record of Cenozoic explosive volcanism in the North Atlantic. In Self, S., and Sparks, R.S.J. (Eds.), Tephra Studies: Dordrecht (Reidel), 289-316.

Walker, G.P.L., 1963. The Breiddalur central volcano, eastern Iceland. $Q . J$. Geol. Soc. London, 119:29-63.

Werner, R., Schmincke, H.-U., and Sigvaldason, G.E., 1996a. A new model for the evolution of tablemountains: volcanological and petrological evidence from Herdubreid and Herdubreidartögl volcanoes (Iceland). Geol. Rundsch. 85:390-397.

Werner, R., Wallrabe-Adams, H.-J., Lacasse, C., Schmincke, H.-U., and Thiede, J., 1996b. Distribution, chemical composition, and sources of Oligocene to Miocene volcanic ashes from Sites 907, 908, and 913. In Thiede, J., Myhre, A.M., Firth, J.V., et al., Proc. ODP, Sci. Results, 151: College Station, TX (Ocean Drilling Program), 333-350.

York, D., 1969. Least-squares fitting of a straight line with correlated errors. Earth Planet. Sci. Lett., 5:320-324.

Date of initial receipt: 7 November 1995

Date of acceptance: 19 June 1996

Ms 152SR-211 


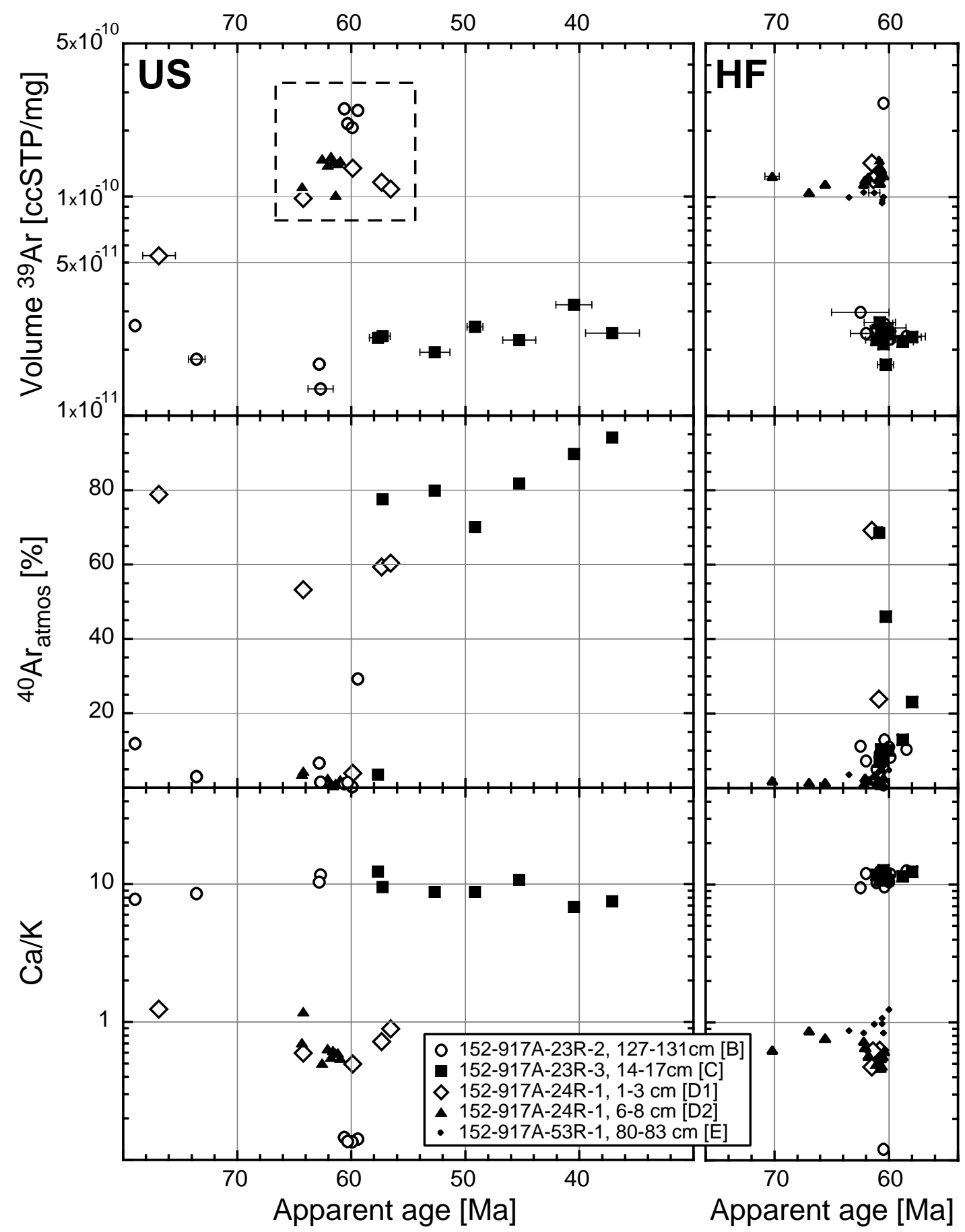

Figure 10. Apparent ${ }^{40} \mathrm{Ar} /{ }^{39} \mathrm{Ar}$ ages vs. potassium content (top $=$ volume ${ }^{39} \mathrm{Ar}_{\mathrm{K}}$; and middle $=$ atmospheric ${ }^{40} \mathrm{Ar}$ content) and $\mathrm{Ca} / \mathrm{K}$ ratio $($ bottom $=$ derived from ${ }^{37} \mathrm{Ar}_{\mathrm{Ca}}{ }^{39} \mathrm{Ar}_{\mathrm{K}}$ ) of feldspar crystals from Paleogene tephra samples B, C, D1, D2, and E (Cores 152-917A-23R, 24R, and 53R).Uppermost diagrams show analytical uncertainties of apparent ages (one sigma error bars, generally smaller than symbol size). Left column (US): First analytical series with ultrasonically cleaned crystals. Dashed box indicates analyses selected to constrain the age of tephra beds B to D1 from this data set. Right column (HF): Second analytical series with crystals that were etched in hydrofluoric acid prior to ultrasonic treatment. Note logarithmic scales in top and bottom diagrams. 
Table 7. Apparent ages, argon isotope composition, and mass of single feldspar crystals from Paleogene tephra deposits (second series) 152-917A-23R2, 127-131 cm (B), 152-917A-23R-3, 14-17 cm (C), 152-917A-24R-1, 1-3 cm (D1), 152-917A-24R-1, 6-8 cm (D2), and 152-917A-53R-1, 80-83 cm (E).

\begin{tabular}{|c|c|c|c|c|c|c|c|}
\hline Sample no. & $\begin{array}{c}\text { Apparent age } \\
(\mathrm{yrs})\end{array}$ & $\begin{array}{l}\text { Error } \\
\text { (yrs) }\end{array}$ & ${ }^{40} \mathrm{Ar}^{*}{ }^{39} \mathrm{Ar}_{\mathrm{K}}$ & $\%^{40} \mathrm{Ar}_{\mathrm{atm}}$ & $\mathrm{Ca} / \mathrm{K}$ & $\begin{array}{l}\text { Mass } \\
(\mathrm{mg})\end{array}$ & $\begin{array}{l}\text { Volume }{ }^{39} \mathrm{Ar} \\
\left(\mathrm{cm}^{3} \mathrm{STP} / \mathrm{mg}\right)\end{array}$ \\
\hline B-i & $6.05 E+7$ & $1.31 \mathrm{E}+5$ & $3.74 \mathrm{E}+1$ & 0.8 & 0.12 & 0.145 & $2.68 \mathrm{E}-10$ \\
\hline B-k & $5.99 \mathrm{E}+7$ & $3.36 \mathrm{E}+5$ & $3.70 \mathrm{E}+1$ & 8.3 & 11.95 & 0.233 & $2.24 \mathrm{E}-11$ \\
\hline B-1 & $6.11 \mathrm{E}+7$ & $5.65 E+5$ & $3.77 \mathrm{E}+1$ & 5.1 & 10.31 & 0.135 & $2.49 \mathrm{E}-11$ \\
\hline B-m & $6.20 \mathrm{E}+7$ & $1.39 \mathrm{E}+6$ & $3.83 \mathrm{E}+1$ & 7.2 & 12.06 & 0.058 & $2.37 \mathrm{E}-11$ \\
\hline B-n & $6.25 \mathrm{E}+7$ & $2.50 \mathrm{E}+6$ & $3.87 \mathrm{E}+1$ & 11.2 & 9.47 & 0.025 & $2.97 \mathrm{E}-11$ \\
\hline B-o & $6.04 \mathrm{E}+7$ & $7.21 \mathrm{E}+5$ & $3.73 E+1$ & 13 & 9.6 & 0.094 & $2.63 \mathrm{E}-11$ \\
\hline B-p & $6.00 \mathrm{E}+7$ & $5.52 \mathrm{E}+5$ & $3.71 \mathrm{E}+1$ & 11 & 10.49 & 0.132 & $2.43 \mathrm{E}-11$ \\
\hline B-q & $5.85 E+7$ & $1.65 \mathrm{E}+6$ & $3.61 \mathrm{E}+1$ & 10.4 & 12.58 & 0.045 & $2.30 \mathrm{E}-11$ \\
\hline B-r & $6.08 \mathrm{E}+7$ & $5.46 \mathrm{E}+5$ & $3.76 \mathrm{E}+1$ & 9.2 & 12.54 & 0.148 & $2.23 \mathrm{E}-11$ \\
\hline C-h & $6.08 \mathrm{E}+7$ & $1.36 \mathrm{E}+6$ & $3.75 \mathrm{E}+1$ & 7 & 10.87 & 0.043 & $2.67 \mathrm{E}-11$ \\
\hline$C-i$ & $6.11 E+7$ & $9.64 \mathrm{E}+5$ & $3.78 \mathrm{E}+1$ & 68.7 & 11.73 & 0.238 & $2.22 \mathrm{E}-11$ \\
\hline C-k & $6.03 E+7$ & $7.12 \mathrm{E}+5$ & $3.73 \mathrm{E}+1$ & 46 & 11.74 & 0.197 & $1.71 \mathrm{E}-11$ \\
\hline C-1 & $5.80 \mathrm{E}+7$ & $8.03 E+5$ & $3.58 \mathrm{E}+1$ & 23.1 & 12.46 & 0.183 & $2.28 \mathrm{E}-11$ \\
\hline $\mathrm{C}-\mathrm{m}$ & $6.01 \mathrm{E}+7$ & $2.21 \mathrm{E}+5$ & $3.71 \mathrm{E}+1$ & 10.1 & 10.79 & 0.739 & $2.38 \mathrm{E}-11$ \\
\hline C-n & $6.07 \mathrm{E}+7$ & $3.01 \mathrm{E}+5$ & $3.75 \mathrm{E}+1$ & 10.4 & 10.75 & 0.41 & $2.38 \mathrm{E}-11$ \\
\hline $\mathrm{C}-\mathrm{O}$ & $6.05 E+7$ & $2.76 \mathrm{E}+5$ & $3.74 \mathrm{E}+1$ & 7.2 & 12.73 & 0.36 & $2.12 \mathrm{E}-11$ \\
\hline C-p & $5.88 \mathrm{E}+7$ & $9.12 \mathrm{E}+5$ & $3.63 \mathrm{E}+1$ & 13 & 11.45 & 0.084 & $2.18 \mathrm{E}-11$ \\
\hline D1-f & $6.09 \mathrm{E}+7$ & $1.69 \mathrm{E}+5$ & $3.77 \mathrm{E}+1$ & 1.4 & 0.61 & 0.117 & $1.22 \mathrm{E}-10$ \\
\hline D1-g & $6.08 \mathrm{E}+7$ & $1.95 \mathrm{E}+5$ & $3.76 \mathrm{E}+1$ & 1.2 & 0.64 & 0.103 & $1.19 \mathrm{E}-10$ \\
\hline D1-h & $6.14 \mathrm{E}+7$ & $1.81 \mathrm{E}+5$ & $3.79 \mathrm{E}+1$ & 2.2 & 0.62 & 0.263 & $1.19 \mathrm{E}-10$ \\
\hline D1-i & $6.08 \mathrm{E}+7$ & $1.38 \mathrm{E}+5$ & $3.76 \mathrm{E}+1$ & 3.7 & 0.53 & 0.23 & $1.30 \mathrm{E}-10$ \\
\hline D1-k & $6.09 \mathrm{E}+7$ & $2.31 \mathrm{E}+5$ & $3.76 \mathrm{E}+1$ & 24.1 & 0.52 & 0.151 & $1.33 \mathrm{E}-10$ \\
\hline D1-1 & $6.14 \mathrm{E}+7$ & $4.97 \mathrm{E}+5$ & $3.80 \mathrm{E}+16$ & 9.2 & 0.48 & 0.042 & $1.41 \mathrm{E}-10$ \\
\hline D2-1 & $6.05 E+7$ & $2.04 \mathrm{E}+5$ & $3.74 \mathrm{E}+1$ & 2.7 & 0.62 & 0.07 & $1.25 \mathrm{E}-10$ \\
\hline D2-m & $6.08 \mathrm{E}+7$ & $1.80 \mathrm{E}+5$ & $3.76 \mathrm{E}+1$ & 0.7 & 0.49 & 0.091 & $1.16 \mathrm{E}-10$ \\
\hline D2-n & $6.56 \mathrm{E}+7$ & $1.20 \mathrm{E}+5$ & $4.06 \mathrm{E}+1$ & 1.4 & 0.77 & 0.146 & $1.14 \mathrm{E}-10$ \\
\hline D2-o & $6.22 \mathrm{E}+7$ & $1.11 \mathrm{E}+5$ & $3.84 \mathrm{E}+1$ & 0.9 & 0.73 & 0.344 & $1.14 \mathrm{E}-10$ \\
\hline D2-p & $7.02 \mathrm{E}+7$ & $6.24 \mathrm{E}+5$ & $4.35 \mathrm{E}+1$ & 1.9 & 0.63 & 0.029 & $1.24 \mathrm{E}-10$ \\
\hline D2-q & $6.06 \mathrm{E}+7$ & $1.19 \mathrm{E}+5$ & $3.74 \mathrm{E}+1$ & 1.2 & 0.57 & 0.347 & $1.26 \mathrm{E}-10$ \\
\hline D2-r & $6.07 \mathrm{E}+7$ & $1.33 \mathrm{E}+5$ & $3.75 E+1$ & 5.2 & 0.55 & 0.168 & $1.33 \mathrm{E}-10$ \\
\hline D2-s & $6.70 \mathrm{E}+7$ & $1.58 \mathrm{E}+5$ & $4.15 \mathrm{E}+1$ & 1.5 & 0.87 & 0.311 & $1.05 \mathrm{E}-10$ \\
\hline $\mathrm{D} 2-\mathrm{t}$ & $6.09 \mathrm{E}+7$ & $2.38 \mathrm{E}+5$ & $3.76 \mathrm{E}+1$ & 1.3 & 0.47 & 0.046 & $1.47 \mathrm{E}-10$ \\
\hline D2-u & $6.12 \mathrm{E}+7$ & $1.77 \mathrm{E}+5$ & $3.78 \mathrm{E}+1$ & 3.3 & 0.5 & 0.111 & $1.37 \mathrm{E}-10$ \\
\hline D2-v & $6.21 \mathrm{E}+7$ & $1.00 \mathrm{E}+5$ & $3.84 \mathrm{E}+1$ & 2.7 & 0.66 & 0.467 & $1.19 \mathrm{E}-10$ \\
\hline D2-w & $6.18 \mathrm{E}+7$ & $9.93 E+4$ & $3.82 \mathrm{E}+1$ & 2 & 0.57 & 0.485 & $1.23 \mathrm{E}-10$ \\
\hline E-a & $6.13 \mathrm{E}+7$ & $4.91 \mathrm{E}+5$ & $3.76 \mathrm{E}+1$ & 0.8 & 0.97 & 0.043 & $1.04 \mathrm{E}-10$ \\
\hline E-b & $6.05 \mathrm{E}+7$ & $1.23 E+5$ & $3.72 \mathrm{E}+1$ & 0.5 & 0.84 & 0.353 & $1.00 \mathrm{E}-10$ \\
\hline E-c & $6.06 \mathrm{E}+7$ & $2.83 \mathrm{E}+5$ & $3.72 \mathrm{E}+1$ & 1.1 & 0.98 & 0.065 & $9.62 \mathrm{E}-11$ \\
\hline E-d & $6.00 \mathrm{E}+7$ & $1.49 \mathrm{E}+6$ & $3.68 \mathrm{E}+1$ & 4.8 & 1.24 & 0.043 & $2.52 \mathrm{E}-11$ \\
\hline E-e & $6.06 E+7$ & $2.59 \mathrm{E}+5$ & $3.72 E+1$ & 1.3 & 1.07 & 0.066 & $9.38 \mathrm{E}-11$ \\
\hline E-f & $5.91 \mathrm{E}+7$ & $5.22 \mathrm{E}+5$ & $3.63 \mathrm{E}+1$ & 3.1 & 1.38 & 0.024 & $1.09 \mathrm{E}-10$ \\
\hline
\end{tabular}




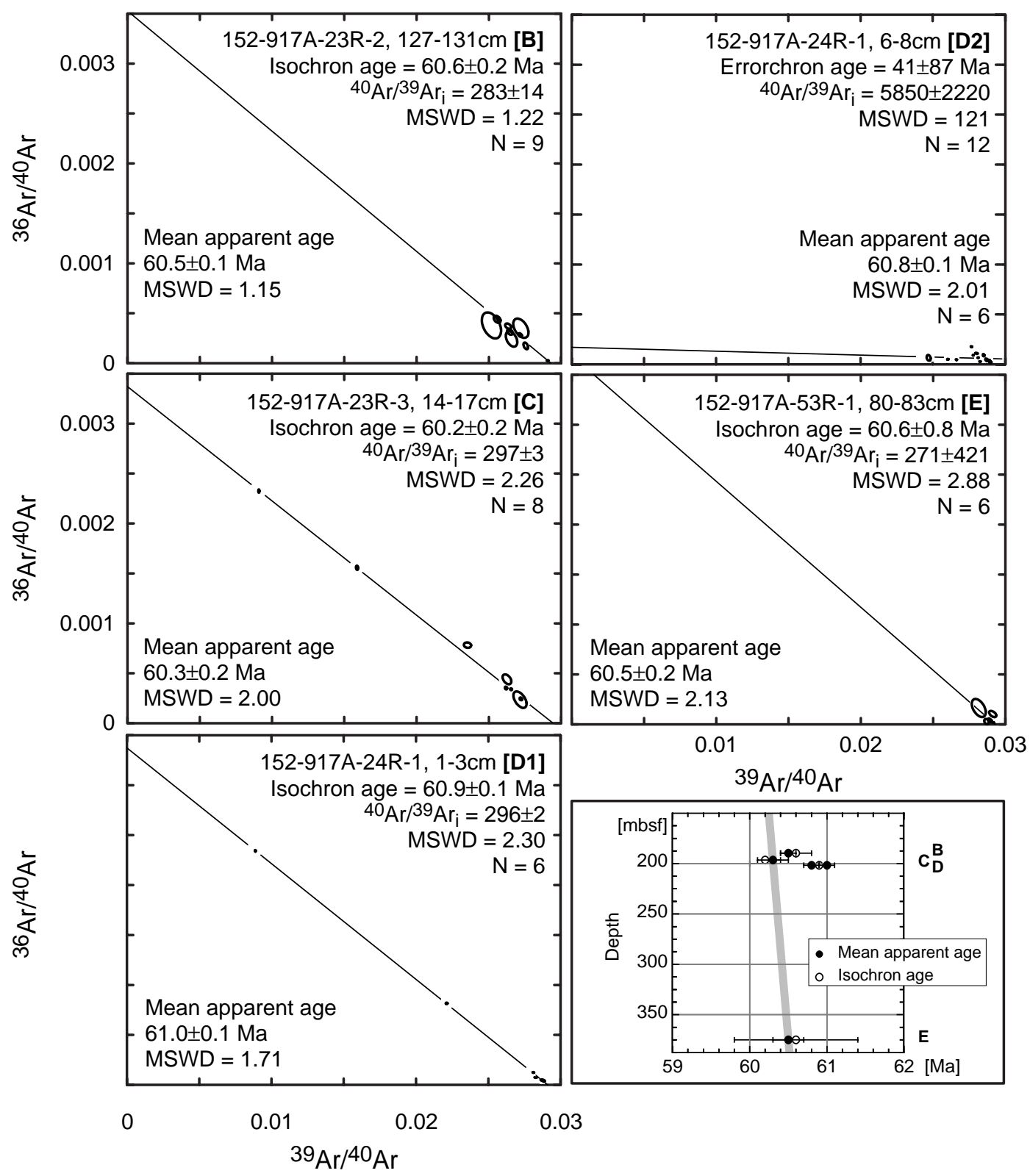

Figure 11. Isotope correlation diagrams showing the Ar isotope composition of feldspar crystals from Paleogene tephra samples B, C, D1, D2, and E (Cores 152-917A-23R, 24R, and 53R; HF-etched crystals), isochrons calculated according to York (1969), and error-weighted mean apparent ages based on initial ${ }^{40} \mathrm{Ar} /{ }^{36} \mathrm{Ar}$ ratios of 295.5. Lower right: Isochron and mean apparent ages (one sigma error bars) vs. depth. 




Plate 1. Photomicrographs of mafic glass particles recovered at Site 918. 1. Dense blocky sideromelane shards representing the dominant vitric clast type in most ash-bearing sediments at Site 918; Sample 152-918A-11H-2, 20-21 cm (Layer 3). 2. Examples of subordinate types of sideromelane shards occurring in ash-bearing deposits at Site 918; Sample 152-918A-12H-2, 30-31 cm (Layer 4). (a) Dense shard containing small plagioclase laths (possibly pillow rim fragment), (b) highly vesicular shard, (c) tubular pumice shard. 


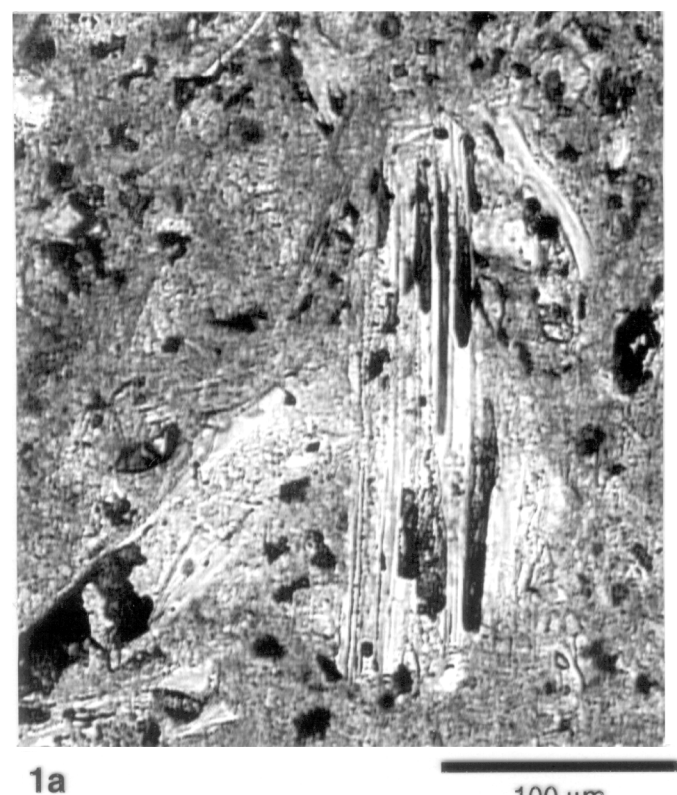

$1 \mathrm{a}$

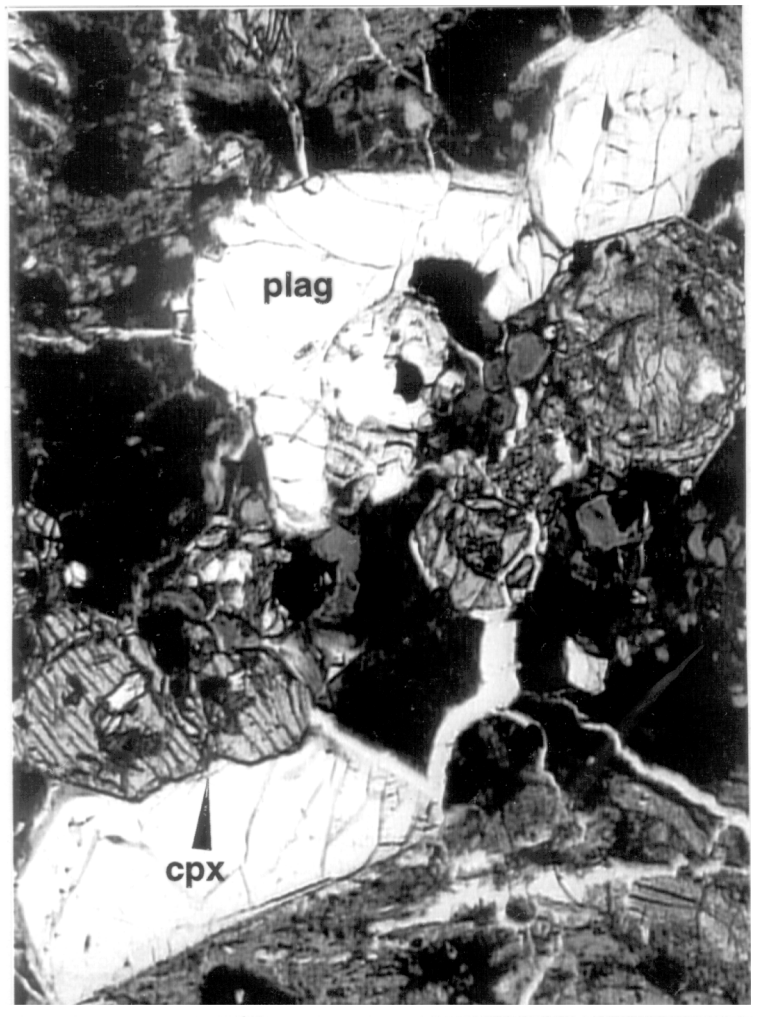

$2 \mathrm{~b}$

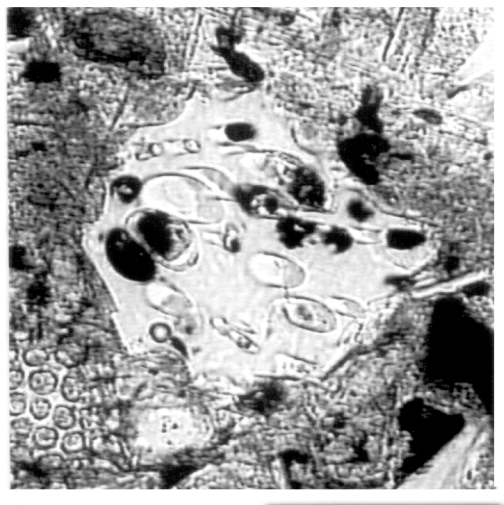

1b

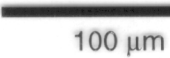

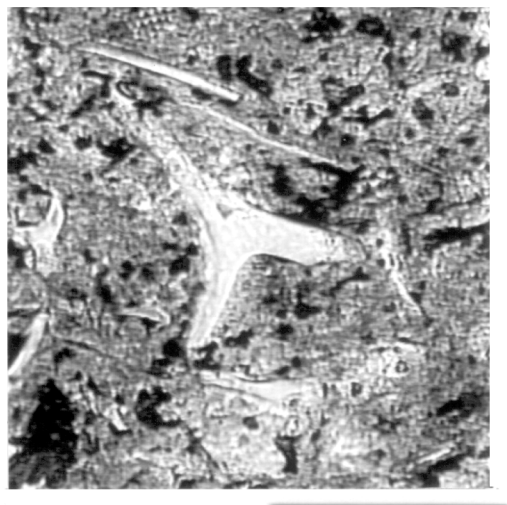

$1 c$

$100 \mu \mathrm{m}$

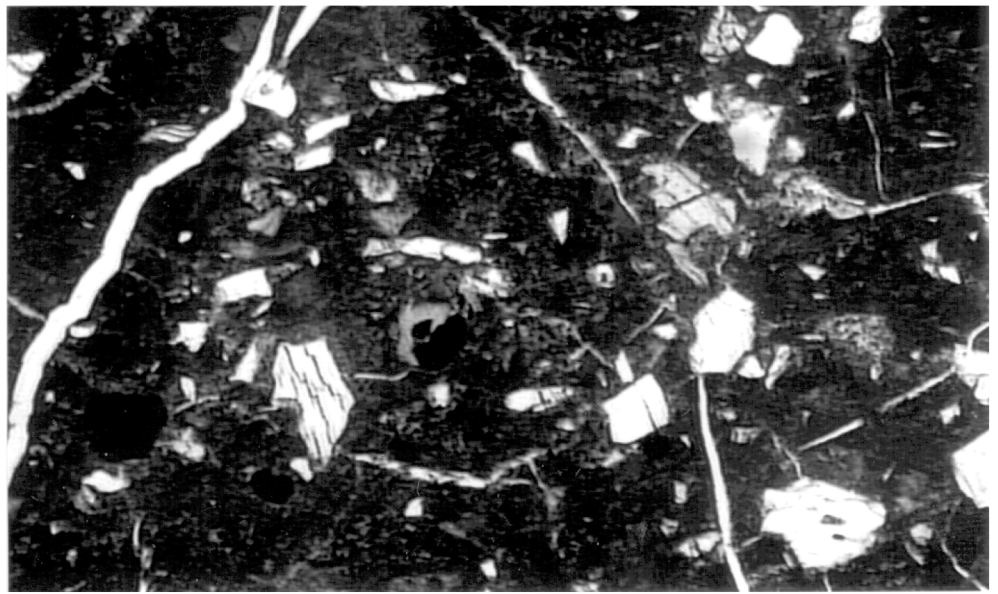

$2 \mathrm{a}$

$1 \mathrm{~mm}$

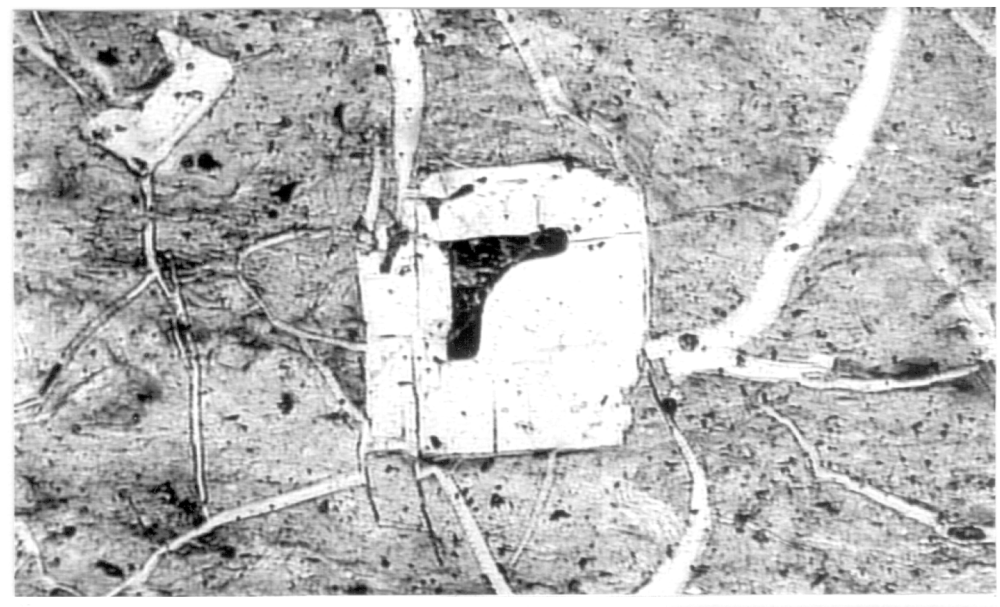

$2 c$

$1 \mathrm{~mm}$

Plate 2. 1. Photomicrographs of felsic glass particles recovered at Site 918; Sample 152-918D-42R-1, 35-36 cm (Layer 20). (a) Pumice shard with parallel alignment of elongated vesicles, (b) pumice shards with circular vesicles, (c) cuspate shard. 2. Photomicrographs of Paleogene volcaniclastic deposits recovered at Site 917. (a) Tuff B: highly fragmented feldspar and clinopyroxene in a reddish clay matrix; Sample 152-917A-23R-2, 127-131 cm; (b) lapillistone C: large euhedral, partly broken feldspar and clinopyroxene crystals in an altered clay matrix; Sample 152-917A-23R-3, 14-17 cm; (c) tuff D: large euhedral feldspar phenocryst in a devitrified matrix; Sample 152-917A-24R-1, 1-3 cm. 